STONE CENTER ON SOCIO-ECONOMIC INEQUALITY

WORKING PAPER SERIES

No. 41

Poverty in the EU Using Augmented Measures of Financial Resources: The Role of Assets and Debt

Sarah Kuypers and Ive Marx

July 2021

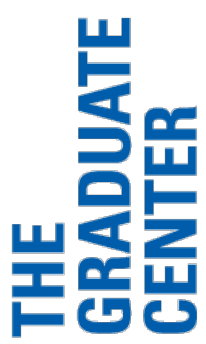

CITY UNIVERSITY

OF NEW YORK 


\title{
Poverty in the EU using augmented measures of financial resources:
}

\author{
the role of assets and debt
}

\author{
Sarah Kuypers \& Ive Marx \\ Herman Deleeck Centre for Social Policy, University of Antwerp
}

\begin{abstract}
Despite clear limitations, poverty research in the rich world overwhelmingly relies on income-based measures. Households may have significant savings and assets that they can draw on to boost their living standards, but may also have debts that depress the living standard they can actually achieve with their disposable income. Using data from the Eurosystem Household Finance and Consumption Survey (HFCS) this paper offers a picture of poverty in $17 \mathrm{EU}$ countries that takes into account assets and debt, using various approaches. While earlier studies have found that poverty rates tend to be lower when wealth is accounted for, this study highlights the situation of those who become or remain poor even when savings and assets are included. It focusses both on within country patterns of joint income-wealth poverty as on cross-country differences. It is shown that the elderly are generally less prone to being poor once assets are accounted for. However, for renter households with a young, female, low educated, unemployed or inactive and single head, the risk of being poor when assets and debt are accounted for remains high and in some cases even increases. That is generally the case because they have few assets, rather than because of high debts. The substantial variation in poverty rates observed across countries can to some extent be accounted for by socio-demographic factors but a lot of variation still remains unaccounted for.
\end{abstract}

Forthcoming in the Journal of European Social Policy. 


\section{Introduction}

Income, usually household disposable income adjusted for household size and composition, is the workhorse variable in most contemporary poverty research. Yet, despite their widespread use income-based measures have some well-known limitations. For instance, apart from the income they may generate, assets and savings are not considered. Previous research has discussed the ways assets matter for living standards and for social and psychological wellbeing (Killewald, Pfeffer and Schachner, 2017; Lerman and McKernan, 2008). Since income and assets are imperfectly correlated it is crucial to take this into account when determining who is poor or financially vulnerable (Kuypers and Marx, 2019). Previous studies (e.g. Brandolini, Magri and Smeeding, 2010; Kuypers and Marx, 2018) suggest that poverty rates are lower when net wealth (i.e. assets minus debt) is included as several households with an income below the poverty line own sufficient assets and savings to lift them above that line. The Covid-19 pandemic has magnified the role of assets in cushioning severe income shocks, as the economic crisis often hit workers loosely protected by the social safety net (e.g. self-employed, gig workers). Yet, households may also have debts that weigh severely on the living standard they can realise with their income. In these cases including net wealth results in some households falling below the poverty line or having a larger poverty gap because their debt is larger than their assets.

This paper contributes to the literature in several ways. First, it offers a picture of poverty in Europe taking into account assets and debt, using various approaches. While earlier studies have focused on a single or a few country case studies (e.g. Azpitarte, 2012; Brandolini, Magri and Smeeding, 2010; Kuypers and Marx, 2018), this is one of the first papers to provide joint income-wealth poverty estimates for a set of 17 EU countries (Austria, Belgium, Cyprus, Estonia, Finland, France, Germany, Greece, Hungary, Ireland, Italy, Luxembourg, Poland, Portugal, Slovak Republic, Slovenia, Spain). These countries differ in income poverty rates, the levels and distributions of wealth as well as the extent to which income and wealth are correlated (Table A.1 in Appendix 1), hence showing the effects of including wealth in poverty measurement in varying institutional settings. Second, while previous studies have mainly focused on the extent to which poverty decreases, we rather highlight the situation of those that become or remain poor even when wealth is included. We show the sociodemographic profile of those who are both income and wealth poor, which differs in some clear respects from those categorised as income poor as traditionally measured. Furthermore, we show to which extent wealth poverty can be attributed to households owning few assets and/or needing to pay off large amounts of debt. 
Making this distinction is very important as they may imply very different policy actions, i.e. asset-building policies versus debt relief programs. Finally, this paper takes a first step in explaining cross-country variation in joint income-wealth poverty rates, based on decompositions that distinguish between differences in the countries' socio-demographic structure and other country level factors.

This paper is organised as follows. In Section 2 we briefly explain the different approaches to measure joint income-wealth poverty and provide an overview of previous studies. The data and methods are discussed in Section 3. In Section 4 we present poverty figures for the total population as well as for children, active age and elderly separately. In Section 5 we focus on explaining poverty patterns within countries by showing who remains (or becomes) poor when wealth is accounted for (i.e. socio-demographic profile) and why they are poor (i.e. low assets and/or high debt). Explaining cross-country variation is discussed in Section 6. The last section concludes and puts forward some policy recommendations.

\section{$2 \quad$ Literature review}

This paper provides a picture of poverty in Europe based on measures which include not only income but also assets and debt. In European and other developed countries financial wellbeing and poverty is traditionally measured using disposable household incomes adjusted for household size. Gradually, income measures have been complemented by material deprivation indicators. However, both have important limitations. Income measures only capture the income generating function of assets (i.e. the fact that assets yield capital income). Yet, assets also provide an insurance against income and consumption shocks, they constitute collateral to borrow against and they are associated with economic and political power. Moreover, wealth has an effect independently from income - on subjective well-being and satisfaction of life (D’Ambrosio, Frick and Jäntti, 2009; Headey and Wooden, 2004; Headey, Muffels and Wooden., 2008). Material deprivation indicators take account of assets only insofar they actually contribute to the (potential) purchase of the items included in the indicator. Perhaps most importantly, both indicators neglect the effects of debt. While public perception and the experience of many people is that debt is one of the most serious problems facing low-income people, it remains largely missing in poverty research. Large debt burdens hamper savings possibilities and for people living on a low income existing debt can spiral out of control when faced with events such as divorce or job loss. High indebtedness also has a profound impact on social and psychological well-being (Fitch et al., 2011). 
Hence, income measures overstate poverty among households with low income but median to high net wealth, while they overlook the precarious situation of households with incomes above the poverty line but with very low assets or bearing a large debt burden. For those who are poor in both dimensions combining them in one indicator acknowledges the interdependence and the fact that not having enough of each resource reinforces vulnerability (Keister and Lee, 2017; Kuypers and Marx, 2019). Given that income and wealth are imperfectly correlated suggests that poverty rates and the socio-demographic profile of the poor might change when wealth is included. Therefore, an expanding literature is arguing in favour of combining income and net wealth to study well-being and poverty (e.g. Jäntti, Sierminska and Smeeding, 2008; OECD, 2013; Stiglitz, Sen and Fitoussi, 2009).

Two approaches have been proposed. The first, developed by Weisbrod and Hansen (1968), integrates income and wealth into a single indicator by transforming the stock of wealth into an annual annuity and adding it to income:

$$
\begin{gathered}
A Y_{t}=Y_{t}+\left[\frac{\rho}{1-(1+\rho)^{-n}}\right] N W_{t-1} \\
n=T \text { for singles, } \quad T_{1}+\left(T-T_{1}\right) b \text { for couples }
\end{gathered}
$$

In this formula $A Y_{t}$ refers to annuitized income in year $t, Y_{t}$ equals income received in year $t, N W_{t-1}$ is net wealth held at the beginning of the year and $\rho$ and $n$ are the interest rate and length of the annuity. The latter is expressed in terms of life expectancies by country, age and gender, where $T_{1}$ refers to time to death of the person who dies first, $T$ time to death of the survivor and $b$ is the reduction in the equivalence scale due to the death of the first person. Income $\left(Y_{t}\right)$ should be interpreted as net of the yield from net wealth because this would be lost if net wealth is depleted (Weisbrod and Hansen, 1968, p.1317).

The second approach adopts a two-dimensional framework by applying a separate poverty line to each dimension and counting the number of dimensions in which people are poor. Income poverty is defined and calculated as traditionally done, while net wealth poverty is considered as having insufficient net wealth to live at a minimally acceptable living standard without any income for a certain period (Brandolini, Magri and Smeeding, 2010; Haveman and Wolff, 2004). Usually, it is calculated as a percentage $(\zeta)$ of the official income poverty line $\left(Z_{t}\right)$ :

Net wealth poverty: $N W_{t-1}<\zeta Z_{t}$ Income poverty: $Y_{t}<Z-r_{t} N W_{t-1}$ 
Four groups are distinguished: (1) those who are income poor, but not wealth poor ('only income poor'), (2) those who are not income poor, but have low assets and/or high debt such that they are wealth poor ('only wealth poor' $)^{1},(3)$ those who are poor in both dimensions ('twice poor') and (4) those who are neither income nor wealth poor. We refer to Brandolini, Magri and Smeeding (2010) and Kuypers and Marx (2018) for a detailed discussion of the two approaches and the impact of methodological choices.

Table 1 provides a (non-exhaustive) list of recent poverty studies applying these approaches. Most adopt the two-dimensional approach (or only study wealth poverty based on this methodology). To provide a broad perspective on joint income-wealth poverty we use both approaches. Also, most studies are limited to one or a few country case studies. In early applications this was mainly the US, which is largely due to early availability of wealth data. Müller and Schmidt (2018) and Balestra and Tonkin (2018) are the only papers that provide estimates for many countries and the HFCS collectors' network also provides some brief insights (HFCN, 2016b). Yet, an important shortcoming is that they use the original HFCS gross incomes. Since poverty rates are normally calculated based on disposable incomes we have simulated these using EUROMOD. The listed studies generally conclude the following: (1) poverty rates are lower when wealth is included, (2) the decline is strongest for the elderly, and (3) the decline is stronger when housing wealth is included compared to when only liquid or financial assets are accounted for (Kuypers and Marx, 2018). Hence, the focus lies primarily on the positive effects of assets lifting some households out of poverty. We rather highlight the situation of those that become or remain poor even when wealth is included. Finally, this is one of the first papers to apply decomposition methods to explain the cross-country variation in wealth poverty rates. So far, only Azpitarte $(2012,2011)$ and Rothwell, Giordono and Robson (2020) have used such techniques in relation to wealth poverty, but they each only compare two countries.

$<$ Table 1>

Besides poverty measurement, similar indicators have been used to study affluence with the aim to differentiate between the 'elite' and 'super-elite' (Keister and Lee, 2017; Peichl and Pestel, 2013) and to study inequality and redistribution (Galluser and Krapf, 2019; Kuypers, Figari and Verbist, 2021, 2019).

\footnotetext{
${ }^{1}$ In the literature the only income poor are also referred to as the protected poor, while the only wealth poor are labelled vulnerable non-poor.
} 


\section{Data and methods}

We use data from the second wave of the Eurosystem Household Finance and Consumption Survey (HFCS), which provides combined information on incomes, assets and debts in a comparative way across European countries. We analyse 17 of the 20 countries participating in the second wave: Austria, Belgium, Cyprus, Estonia, Finland, France, Germany, Greece, Hungary, Ireland, Italy, Luxembourg, Poland, Portugal, Slovak Republic, Slovenia, Spain. The Netherlands, Malta and Latvia are excluded because of small sample sizes. To deal with item nonresponse, the HFCS applies a multiple imputation technique ${ }^{2}$. We present the mean over these imputations.

An important discussion in the literature is which assets and debts are included in the net wealth concept. As can be seen in Table 1 most studies use total net wealth and/or gross liquid assets. Net wealth refers to the difference between all privately owned ${ }^{3}$ assets and all liabilities. The concept of liquid assets ${ }^{4}$ refers to the sum of all assets which can be easily transformed into cash. They are usually studied gross of debts although there are some exceptions. While the first relates to households' long-term financial security, the latter focuses on funds which are immediately available in times of need. The inclusion of owner-occupied housing and pension wealth is hotly debated such that often concepts of net wealth including and excluding these components are compared. Since this paper focuses on poverty and implications for social policy, we aligned our wealth definition to the one that is used in asset-tests of minimum income schemes. Hence, we include wealth components that households ought to spend down (partially) before becoming eligible to minimum income benefits. In most European countries owner-occupied housing and private pensions are exempted from the asset test (Marchal et al., 2020). Therefore, the wealth concept used in this paper also excludes those components. Rothwell, Giordono and Robson (2020) rely on a similar logic, but use gross financial assets as this is the wealth concept relevant for most social benefits in the US and Canada. Table A.2. in Appendix 1 provides results when all wealth components are included.

Income refers to the sum of (self-)employment income, financial income, rental income, public and private pensions, public and private transfers and other types of income (financial and rental income are not included in the annuitization approach). Since the HFCS only covers these incomes gross of taxes and social security contributions, we have used the EU-wide tax-benefit microsimulation model EUROMOD to estimate disposable

\footnotetext{
2 For more information on the imputation strategy see HFCN (2016a). Finland, France, Italy and Ireland do not use multiple imputations.

3 Public wealth such as entitlements to public pensions are not included.

${ }^{4}$ Some studies use financial assets rather than liquid assets. Although they largely overlap, the first may include less liquid financial assets such as private pensions and may exclude relatively liquid real assets such as vehicles.
} 
incomes. Incomes, assets and debts have been uprated from their survey reference period to price levels of 2017 such that 2017 policies are applied to simulate disposable incomes. A brief description of how disposable incomes are derived is provided in Appendix 2, for more detailed information we refer to Boone et al. (2019). Both income and wealth are equivalised using the OECD modified scale ${ }^{5}$.

Poverty rates are calculated as follows. For income poverty we apply the EU at-risk-of-poverty line, defined as 60 percent of national median equivalised disposable income. The two approaches to joint income-wealth poverty are calculated based on the formulas above and applying the standard methodological choices of the literature. For the annuitization approach this means that the stock of wealth ${ }^{6}$ is transformed into an annuity by applying a $2 \%$ interest rate $(\rho)$ and life expectancies by country, age and gender $(n)$ from EUROSTAT. ${ }^{7}$ Typically, the poverty line is kept at the same level as for conventional income poverty, which is in line with the idea that it reflects a truly minimally acceptable living standard. Another option would be to include wealth also in determining the poverty line (Brandolini, Magri and Smeeding, 2010). Since this distinction has an important effect (Kuypers and Marx, 2018), we show both options. Although some authors have used absolute wealth poverty lines (e.g. Headey, 2008), we stick to relative ones. This way we adhere to the European Union's view on poverty as being relative and it makes it easier to interpret the differences with income poverty. Therefore, in the annuity approach the poverty line is either fixed or set at $60 \%$ of the national median equivalised income + annuitized net wealth. In the two-dimensional approach the wealth poverty line is set at $1 / 4^{\text {th }}$ of the income poverty line; i.e. households are considered wealth poor when they own insufficient wealth to be able to sustain a living standard at the income poverty line for three months without any income. Although essentially arbitrary, the three month period was inspired by the fact that wealth is often needed to bridge unemployment spells, for which the expected duration in the US prior to the financial crisis was between two and four months (Caner and Wolff, 2004). Such a rationale may be less applicable to the European context with often longer unemployment

\footnotetext{
5 There is no consensus on whether it is appropriate to equivalise wealth and if so which scale is relevant. Yet, when considering wealth as a resource supporting current consumption, as we do in this paper, it is generally considered appropriate to apply the same equivalence scale to income and wealth (OECD, 2013, p.178). The majority of literature also uses equivalence scales.

${ }^{6}$ The formula takes net wealth at the beginning of the income reference period, while the HFCS observes net wealth at the end or even several months after the income reference period. To tackle this issue we subtract from net wealth observed in the HFCS the amount of financial income that is received throughout the year as a proxy for the growth of net wealth.

7 Since age is top coded at 85 years in the HFCS, we cannot assign the correct life expectancies to these individuals. Therefore we restrict our sample to households where both partners are maximum 84 years old.
} 
spells, but also with better public safety nets in place. Yet, the three-month poverty line is still most often used.

Table A.3. in Appendix 1 lists the country specific poverty lines.

In Section 5 we run a logistic regression to determine the socio-demographic profile of those at risk of joint income-wealth poverty. We include the age, gender, educational attainment and labour status of the household head, the household type and tenure status. Having a migrant background is not included because it is missing for Spain. Finally, in Section 6 we aim to explain the cross-country variation in poverty rates by decomposing them into a part that is explained by socio-demographic differences and another residual part that covers all other possible explanatory factors, such as institutional, economic and cultural factors. In particular, we apply a Blinder-Oaxaca decomposition for binary variables (Fairlie, 2005) and disaggregate the explained part into the separate contributions of each socio-demographic characteristic (see e.g. Sierminska and Doorley, 2018 for a more detailed explanation).

\section{$4 \quad$ Patterns of joint income-wealth poverty in Europe}

We first discuss poverty rates when applying the different approaches to joint income-wealth poverty. Table 2 shows the results for the total population as well as for children, active age and elderly separately. ${ }^{8}$ In line with previous research poverty rates for the total population and each age group decrease when annuitized net wealth is added to income and compared to the same poverty line. Yet, there are large cross-country variations. For the total population, the poverty rate decreases by between 0.1 percentage points in Finland and 3.9 percentage points in Cyprus, with a cross-country average of 2.1 percentage points. When using a fully relative approach, the poverty line increases (Table A.3. in Appendix 1). This results in higher poverty rates. For children and those at active age, poverty rates in the fully relative approach are higher than the conventional income poverty rates. This follows from the fact that wealth is far more unequally distributed than income. Only for the elderly joint income-wealth poverty rates are often lower than income poverty rates. In Cyprus, France, Hungary, Slovak Republic, Slovenia and Spain elderly joint income-wealth poverty is also higher than income poverty. In Poland it is the other way around; the elderly have higher poverty rates, while the active age and children have

\footnotetext{
${ }^{8}$ Children are aged less than 18 years, active age are between 18 and 64 years old and elderly are aged 65 and older. In contrast to the logistic regression, where we use the age of the household head, here the age of each individual is used.
} 
lower poverty rates. Hence, for the majority of the population the conclusion of the literature that poverty is lower when wealth is included only holds when the poverty line is not adapted.

$<$ Table 2>

Applying the two-dimensional approach shows that on average about 55 percent of the income poor own sufficient assets to bridge a three-month period at the income poverty line. The remainder are both income and wealth poor and therefore the most vulnerable. Again, important differences exist across countries. Only about 27 percent of the income poor are also wealth poor in Spain, while this is more than 60 percent in Finland and Slovak Republic. Furthermore, between 7.6 percent of people in Spain and 33.5 percent in Finland are currently not regarded as poor, but they have negative or little net wealth such that they are vulnerable to income and consumption shocks. As in the annuity approach, in most countries poverty is lowest among the elderly.

A cross-country comparison shows that the country ranking remains relatively similar across the different approaches (scatterplots are presented in Figure A.1. in Appendix 1). For instance, Austria and Finland have low poverty rates in all approaches. Yet, Finland, interestingly, has the highest share of 'only net wealth poor'. Italy, Ireland and Estonia score badly on all poverty approaches. However, countries with low income poverty rates do not necessarily have low wealth poverty rates and vice versa. Spain, for instance, has one of the highest income poverty rates, but a relatively low share of people who are both income and wealth poor.

\section{Within country explanations of joint income-wealth poverty}

To explain joint income-wealth poverty patterns within countries, we need to address two questions. First, who remains (or becomes) poor even when net wealth is accounted for? Second, why are they poor in that approach? Regarding the first question, Table 3 provides insight into the socio-demographic risk profile of joint incomewealth poverty as compared to conventional income poverty. In particular, logistic regressions are run on the annuitized approach with the adjusted poverty line, the twice poor rate and the income poverty rate. Particularly households who are tenants or free users of the residence they live in and those who have a young, female, low educated, unemployed or inactive and single household head are at high risk of remaining or becoming poor even when net wealth is included. The risk profile is similar to the one for income poverty, but the education gradient is more outspoken, as is the case for tenure status. Since owner-occupied housing is not included in net wealth this implies that tenants do not make up the missing real estate wealth by owning financial wealth. In 
contrast, the self-employed generally have a high risk of income poverty, but it decreases substantially when net wealth is accounted for. They have a much lower risk of being twice poor than any other labour market status.

<Table 3>

The second question we address in this section is the reason why these households remain (or become) poor. Low net wealth may be the consequence of having low assets and/or having high debt. These reflect very different precarious situations and hence require different policy responses. Households being wealth poor because of low assets may be supported by so-called asset-building policies, while those struggling mainly with high debt may benefit from debt relief programs. Therefore, Table 4 divides the overall poverty rates of the fully relative annuitization approach and the twice poor rate by main reason for being poor, i.e. reason for having low (or negative) net wealth. The division is made as follows: non-over-indebted households are those who have zero debt or a debt-to-asset ratio lower than $75 \%{ }^{9}$, when the debt-to-asset ratio is higher than $75 \%$ but the household would no longer be regarded as poor if gross wealth would be used to calculate poverty rates (i.e. assets are sufficiently high to not be considered poor) they are labelled as over-indebted asset-non-poor, and when the debt-to-asset ratio is higher than $75 \%$ and the household would still be poor if gross wealth was used to calculate poverty they are labelled as over-indebted asset-poor. In other words, the first group has low assets, but no immediate debt issues, the second group has sufficient gross assets, but high debt makes them wealth poor, while the last group has both low assets and high debt. Table 4 shows the incidence of these reasons. Although there is some variation, in all countries the majority of people who are counted as both income and wealth poor qualify as such because they have low assets. The second most important reason is having both low assets and high debt. In other words, the majority would still be considered poor if they had no debt.

$<$ Table 4>

In Table A.4. in Appendix 1 we also provide the results of multinomial logistic regressions of socio-demographics on the different reasons for being joint income-wealth poor. It shows among others that the effect of education is lower for having high debt, but sufficient gross assets as main reason for being poor than for the other two

\footnotetext{
${ }^{9}$ A debt-to-asset ratio of more than $75 \%$ is generally considered the limit for being over-indebted (see for instance Balestra and Tonkin, 2018).
} 
reasons. The impact of unemployment or inactivity is strongest for the over-indebted asset-poor. The same is true for tenure status.

\section{Cross-country explanations of joint income-wealth poverty}

In this section we study to which extent the cross-country variation in joint income-wealth poverty rates can be explained by differences in the countries' socio-demographic structure. As Table 3 showed, households who are tenants or free users and those who have a young, female, low educated, unemployed or inactive and single household head are at high risk of being poor. Hence, countries where relatively more of such people live might have higher wealth poverty rates. Besides socio-demographic characteristics also differences in institutional, economic and cultural factors can influence wealth poverty rates. Brady, Finnigan and Hübgen (2017) refer to the first as prevalences, i.e. the share of the population belonging to a risk group, while the latter are penalties, defined as the increased probability of poverty associated with belonging to a risk group. To differentiate between these two groups of explanatory factors we decompose the total difference in poverty rates between a base country and each other country ('raw difference') in an explained part (i.e. variation due to differences in socio-demographics) and a residual unexplained part (i.e. variation due to differences in other factors), where the first is further disaggregated to show the contribution of each characteristic. ${ }^{10}$ We use Austria as base country as it has the lowest poverty rates. Hence, the explained part provides counterfactual poverty rates, i.e. how poverty rates would change if the other countries would have the same socio-demographic structure as Austria.

The results are shown in Table 5. First, in most cases less than a third of the poverty gap is explained by differences in socio-demographics or the explained effect goes in the opposite direction (i.e. negative explained difference). The latter implies that based on socio-demographics alone a smaller difference in poverty between Austria and the respective country is expected. In other words, in these cases country level factors increase the relative poverty risk in the respective country compared to Austria. The explained difference is higher than the raw difference for France in both poverty approaches and for Luxembourg and Spain for the twice poor rate. This means that the differences in socio-demographics would predict an even larger poverty gap with Austria than is actually observed such that country level factors reduce the relative poverty risk of those who are most vulnerable to being wealth poor in these countries. Finally, tenure status is an important variable explaining

10 We apply random sequencing to determine the separate contributions of the different characteristics. 
poverty risks within countries (Table 3), but also between countries. For most countries tenure has a negative sign, such that it contributes to decreasing the poverty gap with Austria, i.e. differences in tenure status result in lower poverty rates. Labour market status is generally the second most important household level explanatory factor. While age is a relatively important factor explaining poverty risk within countries, it hardly explains differences between countries.

$<$ Table 5>

In short, despite the important impact of tenure status, household level variables often account for only a small part of the total variation in joint income-wealth poverty rates. Hence, this leaves a lot of room for explanatory factors at the country level. One can think of a host of factors playing a role. Pension policies influence the propensity to accumulate private savings. These may be amplified by factors like government mistrust or foresightedness. Housing policies, especially tax incentives, encourage house acquisition in some countries, while others rely more strongly on rental markets (Dewilde and Flynn, 2021). The cost of education may play a role as student loans are a major source of debt in some countries. One can think of lots of other factors playing a role, including restrictions on consumer credit or bank lending.

\section{Conclusion and policy discussion}

Measures of financial vulnerability and poverty overwhelmingly build on household disposable income. Yet, income poor people sometimes hold significant assets which they can draw on to make up for income shortfalls. Yet, they may also face significant debts that weigh on the living standards they can effectively realize with their income.

This article looks at poverty in Europe taking account of assets and debt in various ways. The literature generally concludes that poverty declines when wealth is included. We have demonstrated that this does not hold in a fully relative approach, i.e. when the poverty line is also determined in terms of both income and (annuitized) wealth. If we consider people "wealth poor" when they do not own sufficient net wealth that would enable them to sustain a living standard at the income poverty line for three months the picture is generally more favourable. This holds especially for the elderly. Importantly, child poverty remains high even when wealth is accounted for. The effect of including net wealth in poverty measurement differs across countries, but in general the country 
ranking remains relatively similar across approaches. This is, however, not always the case. Spain, for instance, has one of the highest income poverty rates, but a relatively low share of people who are both income and wealth poor. Hence, taking into account wealth has an important effect on within country poverty patterns, but sometimes also on between country rankings. We therefore encourage researchers to include wealth in poverty analyses - and more broadly distributional analyses - as much as possible. Each approach has its merits and slightly focuses on different aspects of poverty. However, the idea of bridging a certain period without any income is very much based on US experiences, where a private safety net in the form of wealth is very important to face such periods (see the contribution by Rodems and Pfeffer, 2021 in this special issue). In the European context public safety nets are stronger such that periods without any income are less relevant and wealth is rather a complementary buffer than the only one. Therefore, the annuity approach is probably preferred over the two-dimensional one. Whether or not the poverty line should be adapted remains debatable, though given the large differences very important. At the moment there still appears to be consensus that the at-risk-ofpoverty line more or less reflects a minimally acceptable living standard, also because they correspond relatively well to budget standards in at least several countries (Penne et al., 2016). However, if we are moving towards what Piketty (2020) has called 'neo-proprietarian' societies in which wealth is becoming the primary source of living standards then it might be considered more appropriate to define poverty along those lines.

This paper also set out on explaining joint income-wealth poverty rates within and between countries. First, particularly households who are tenants or free users of the residence they live in and those who have a young, female, low educated, unemployed or inactive and single household head are at high risk of being both income and wealth poor. The risk profile is similar to the one for income poverty, but the education gradient is more outspoken. Also, the vulnerable situation of renters becomes even more obvious once assets and debt are accounted for. Since the value of the main residence is not included in the wealth definition this implies that tenants do not make up the missing real estate wealth by owning financial wealth. We also looked at the main reason why households are still being counted as poor even when wealth is included: whether it is due to having low assets, high debt or a combination of the two. In all countries the majority of people are poor because they have few assets and they would still be considered poor even without any debt.

These results have important policy implications. First, they indicate in which areas social spending should be prioritized and if increased targeting within those areas is decided upon to which vulnerable groups it should 
primarily focus. Our results clearly call for prioritising policies aimed at reducing child poverty, policies focused at low educated people and policies supporting renters. Increased targeting could be achieved by implementing asset-testing, which often already exists in minimum income protection (Marchal et al., 2021). However, such asset-testing runs the risk of discouraging wealth accumulation among those with low incomes. Therefore, it is also crucial to understand the main reason why households remain poor even when wealth is accounted for - or in other words the reason why they have low net wealth. Those who have high debt would benefit from debt mediation or even alleviation. However, most households with low net wealth simply have very few assets. This calls for investigating the possibilities of so-called asset-building policies. Although most European countries encourage the ownership of real estate and financial assets through tax reliefs, these policies are typically unavailable to the poor. Therefore, exploring new types of asset policies might prove an interesting addition to income-based social provisions. One can think of short-term policies in the spirit of the US' Individual Development Accounts (IDA's) (Sherraden, 1991) and/or longer-term policies such as a minimum inheritance or endowment received at the start of adulthood (Atkinson, 2015; see also Morelli et al., 2021 in this Special Issue). Social policy research still largely focuses on income-based policies and how policies affect the distribution of income. Future research should pay more attention to how policies affect the wealth distribution and how they can be used to reduce joint income-wealth poverty and inequality.

This paper also investigated to what extent cross-country variation in joint income-wealth poverty rates are explained by differences in the countries' socio-demographic structures. Tenure status is again the most important explanatory variable, but in most cases household level variables account for only a small part of the total variation. This paper thus opens up further avenues for research since a lot of variation across countries remains unaccounted for. Of course, wealth accumulations occur over many generations. They are the product of ownership patterns that have long histories. Yet, there remains an important research agenda for scholars of contemporary social and economic policy to explain the vast differences across countries, especially when it comes to asset ownership and debt patterns among those who are conventionally classified as income poor. Housing and public pension policies stand out as particularly relevant in this context. As Dewilde and Flynn (2021) point out in their contribution to this special issue, some countries can be considered home-ownership societies, while others are rather reliant on well-functioning rental markets. Cross-country differences in the average level and concentration of wealth are reflective of this. In future research the effects of such variation in institutional 
settings, economic environments, historical divides and cultural backgrounds could be considered. Verbunt and Guio (2019), for example, use multilevel modelling to explain within and between country differences in the risk of income poverty, severe material deprivation and their overlap. A similar strategy could be applied to income and wealth poverty.

In the current paper we focus on calculating and explaining poverty patterns based on income and wealth observed at a single point in time. Although adding information on wealth provides more information on the long-term economic (and social) security of households, permanent income and permanent wealth would be even better measures of economic and social well-being (e.g. Brady et al., 2018; D’Ambrosio, Jäntti and Lepinteur, 2020). Because of data limitations such analyses are not yet commonplace. However, with increasingly more data becoming available we encourage researchers to consider expanding the time horizon in their analyses. 


\section{References}

Aratani, Y. \& Chau, M., 2010. Asset poverty and debt among families with children, New York: National Center for Children in Poverty, Columbia University Mailman School of Public Health, 11p..

Atkinson, A. B., 2015. Inequality. What can be done?. s.I.:Harvard University Press.

Azpitarte, F., 2011. Measurement and identification of asset poor households: a cross-national comparison of Spain and the United Kingdom. Journal of Economic Inequality, 9(1), pp. 87-110.

Azpitarte, F., 2012. Measuring poverty using both income and wealth: A cross-country comparison between the U.S. and Spain. Review of Income and Wealth, 58(1), pp. 24-50.

Balestra, C. \& Tonkin, R., 2018. Inequalities in household wealth across OECD countries. Evidence from the OECD wealth distribution database, OECD Statistics Working Paper 2018/01, OECD Publishing: Paris.

Blumenthal, A. \& Rothwell, D. W., 2018. The measurement and description of child income and asset poverty in Canada. Child Indicators Research, 11(6), pp. 1907-1933.

Boone, J. et al., 2019. EWIGE 2 - Update and extension of the EUROMOD wealth taxation project, s.I.: JRC Working papers on Taxation and Structural Reforms No. 2019/07.

Brady, D., Finnigan, R. M. \& Hübgen, S., 2017. Rethinking the risks of poverty: A framework for analyzing prevalences and penalties. American Journal of Sociology, 123(3), pp. 740-786.

Brady, D., Giesselmann, M., Kohler, U. \& Radenacker, A., 2018. How to measure and proxy permanent income: evidence from Germany and the U.S.. Journal of Economic Inequality, 16(3), pp. 321-345.

Brandolini, A., Magri, S. \& Smeeding, T., 2010. Asset-based measurement of poverty. Journal of Policy Analysis and Management, 29(2), pp. 267-284.

Caner, A. \& Wolff, E. N., 2004. Asset poverty in the United States, 1984-99: Evidence from the Panel Study of Income Dynamics. Review of Income and Wealth, 50(4), pp. 493-518.

D'Ambrosio, C., Frick, J. R. \& Jäntti, M., 2009. Satisfaction with life and economic well-being: Evidence from Germany. Schmollers Jahrbuch: Journal of Applied Social Science Studies / Zeitschrift für Wirtschafts- und Sozialwissenschaften, 192(2), pp. 283-295.

D'Ambrosio, C., Jäntti, M. \& Lepinteur, A., 2020. Money and happiness: Income, wealth and subjective wellbeing. Social Indicators Research, 148(1), pp. 47-66.

Dewilde, C. \& Flynn, L., 2021. Post-crisis developments in young adults' housing wealth. Journal of European Social Policy, Issue Special Issue on Wealth and Social Policy.

Eurostat, 2013. Data matching - Final report ESTAT study. Case study on income and wealth (SILC-HFCS), s.I.: Document LC-LEGAL/19/13 presented at the 7th meeting of the Task force on the revision of the EU-SILC legal basis 5-6 december 2013.

Eurosystem Household Finance and Consumption Network (HFCN), 2016a. The Household Finance and Consumption Survey: methodological report for the second wave, s.I.: ECB Statistics Paper No.17.

Eurosystem Household Finance and Consumption Network (HFCN), 2016b. The Household Finance and Consumption Survey: results from the second wave, s.I.: ECB Statistics Paper No.18. 
Fairlie, R. W., 2005. An extension of the Blinder-Oaxaca decomposition technique to logit and probit models. Journal of Economic and Social Measurement, 30(4), pp. 305-316.

Fitch, C., Hamilton, S., Basset, P. \& Davey, R., 2011. The relationship between personal debt and mental health: a systematic review. Mental Health Review Journal, 16(4), pp. 153-166.

Galluser, D. \& Krapf, M., 2019. Joint income-wealth inequality: An application using administrative tax data, s.I.: CESifo Working Paper No. 7876.

Gornick, J. C., Munzi, T., Sierminska, E. \& Smeeding, T. M., 2009. Income, assets and poverty: Older women in comparative perspective. Journal of Women, Politics \& Policy, 30(2-3), pp. 272-300.

Haveman, R. \& Wolff, E. N., 2004. The concept and measurement of asset poverty: Levels, trends and composition for the U.S., 1983-2001. Journal of Economic Inequality, 2(2), pp. 145-169.

Headey, B., 2008. Poverty is low consumption and low wealth, not just low income. Social Indicators Research, 89(1), pp. 23-39.

Headey, B., Muffels, R. \& Wooden, M., 2008. Money does not buy happiness: Or does it? A reassessment based on the combined effects of wealth, income and consumption. Social Indicators Research, 87(1), pp. 65-82.

Headey, B. \& Wooden, M., 2004. The effects of wealth and income on subjective well-being and ill-being. The Economic Record, 80(S1), pp. S24-S33.

Huang, J. et al., 2013. Asset poverty in urban China: A study using the 2002 Chinese household income project. Journal of Social Policy, 42(4), pp. 763-781.

Jäntti, M., Sierminska, E. \& Smeeding, T., 2008. The joint distribution of household income and wealth. Evidence from the Luxembourg Wealth Study. Paris, OECD Publishing.

Keister, L. A. \& Lee, H. Y., 2017. The double one percent: Identifying an elite and a super-elite using the joint distribution of income and net worth. Research in Social Stratification and Mobility, Volume 50, pp. 1-12.

Killewald, A., Pfeffer, F. T. \& Schachner, J. N., 2017. Wealth inequality and accumulation. Annual Review of Sociology, Volume 43, pp. 379-404.

Kim, K. S. \& Kim, Y. M., 2013. Asset poverty in Korea: Levels and composition based on Wolff's definition. International Journal of Social Welfare, 22(2), pp. 175-185.

Kuypers, S., Figari, F. \& Verbist, G., 2019. Redistribution in a joint income-wealth perspective. A cross-country analysis. Socio-Economic Review.

Kuypers, S., Figari, F. \& Verbist, G., 2021. Redistribution in a joint income-wealth perspective: A comparison across 16 countries, OECD Social, Employment and Migration Working Paper No.257, OECD Publishing: Paris.

Kuypers, S. \& Marx, I., 2018. Estimation of joint income-wealth poverty: A sensitivity analysis. Social Indicators Research, 136(1), pp. 117-137.

Kuypers, S. \& Marx, I., 2019. The truly vulnerable: integrating wealth into the measurement of poverty and social policy effectiveness. Social Indicators Research, 142(1), pp. 131-147.

Lerman, R. \& McKernan, S., 2008. The effects of holding assets on social and economic outcomes of families: a review of theory and evidence, s.l.: Report in the series 'Poor Finances: Assets and low-income households. The Urban Institute. 
Marchal, S., Kuypers, S., Marx, I. \& Verbist, G., 2021. But what about that nice house you own? The impact of asset tests in minimum income schemes in Europe: an empirical exploration. Journal of European Social Policy, 31(1), pp. 44-61.

Morelli, S., Nolan, B., Palomino, J. \& Van Kerm, P., 2021. Inheritances, gifts and the accumulation of wealth for low-income households. Journal of European Social Policy.

Müller, P. \& Schmidt, T., 2018. Identifying income and wealth-poor households in the Euro Area. Journal of Poverty, 22(2), pp. 126-155.

OECD, 2013. OECD Framework for Statistics on the Distribution of Household Income, Consumption and Wealth, Paris: OECD Publishing.

Peichl, A. \& Pestel, N., 2013. Multidimensional affluence: theory and applications to Germany and the US. Applied Economics, 45(32), pp. 4591-4601.

Penne, T. et al., 2016. Can reference budgets be used as a poverty line?, s.I.: ImPRovE Working Paper No.16/05.

Piketty, T., 2020. Capital and ideology. Cambridge: Harvard University Press.

Rothwell, D. \& Robson, J., 2018. The prevalence and composition of asset poverty in Canada: 1999, 2005, and 2012. International Journal of Social Welfare, 27(1), pp. 17-27.

Rothwell, D. W., Giordono, L. S. \& Robson, J., 2020. Public income transfers and wealth accumulation at the bottom: Within and between country differences in Canada and the United States. Social Policy \& Administration, 54(6), pp. 914-932.

Sherraden, M., 1991. Assets and the poor. A new American welfare policy. Armonk, New York: M.E. Sharpe Inc..

Sierminska, E. \& Doorley, K., 2018. To own or not to own? Household portfolios, demographics and institutions in a cross-national perspective. Journal of Income Distribution, 25(1), pp. 1-43.

Stiglitz, J. E., Sen, A. \& Fitoussi, J.-P., 2009. Report by the Commission on the Measurement of Economic Performance and Social Progress, s.I.: s.n.

Sutherland, H. \& Figari, F., 2013. EUROMOD: the European Union tax-benefit microsimulation model. International Journal of Microsimulation, 6(1), pp. 4-26.

Van den Bosch, K., 1998. Poverty and assets in Belgium. Review of Income and Wealth, 44(2), pp. 215-228.

Verbunt, P. \& Guio, A.-C., 2019. Explaining differences within and between countries in the risk of income poverty and material deprivation: Comparing single and multilevel analysis. Social Indicators Research, 144(2), pp. 827-868.

Weisbrod, B. A. \& Hansen, W. L., 1968. An income-net worth approach to measuring economic welfare. American Economic Review, 58(5), pp. 1315-1329. 


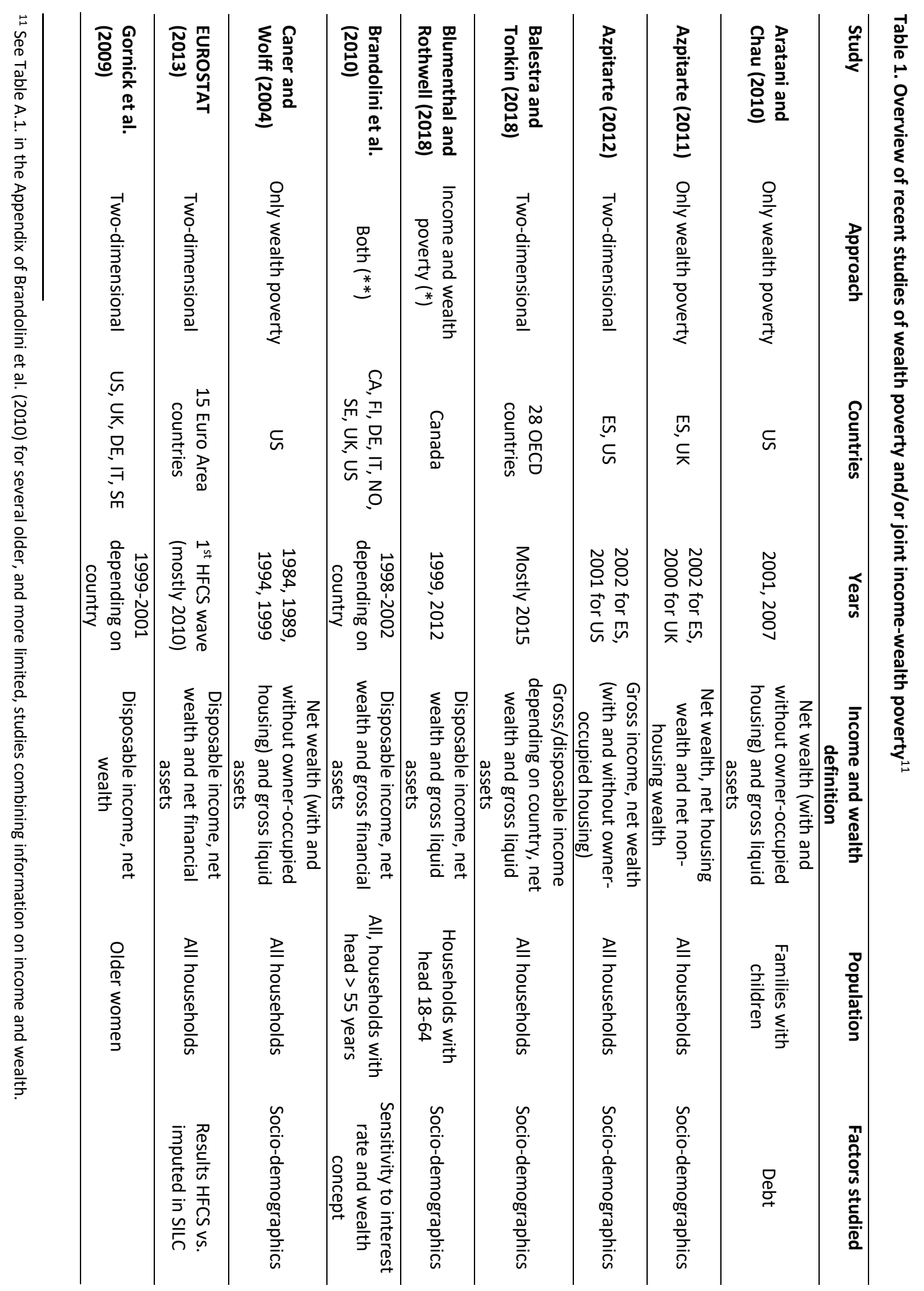




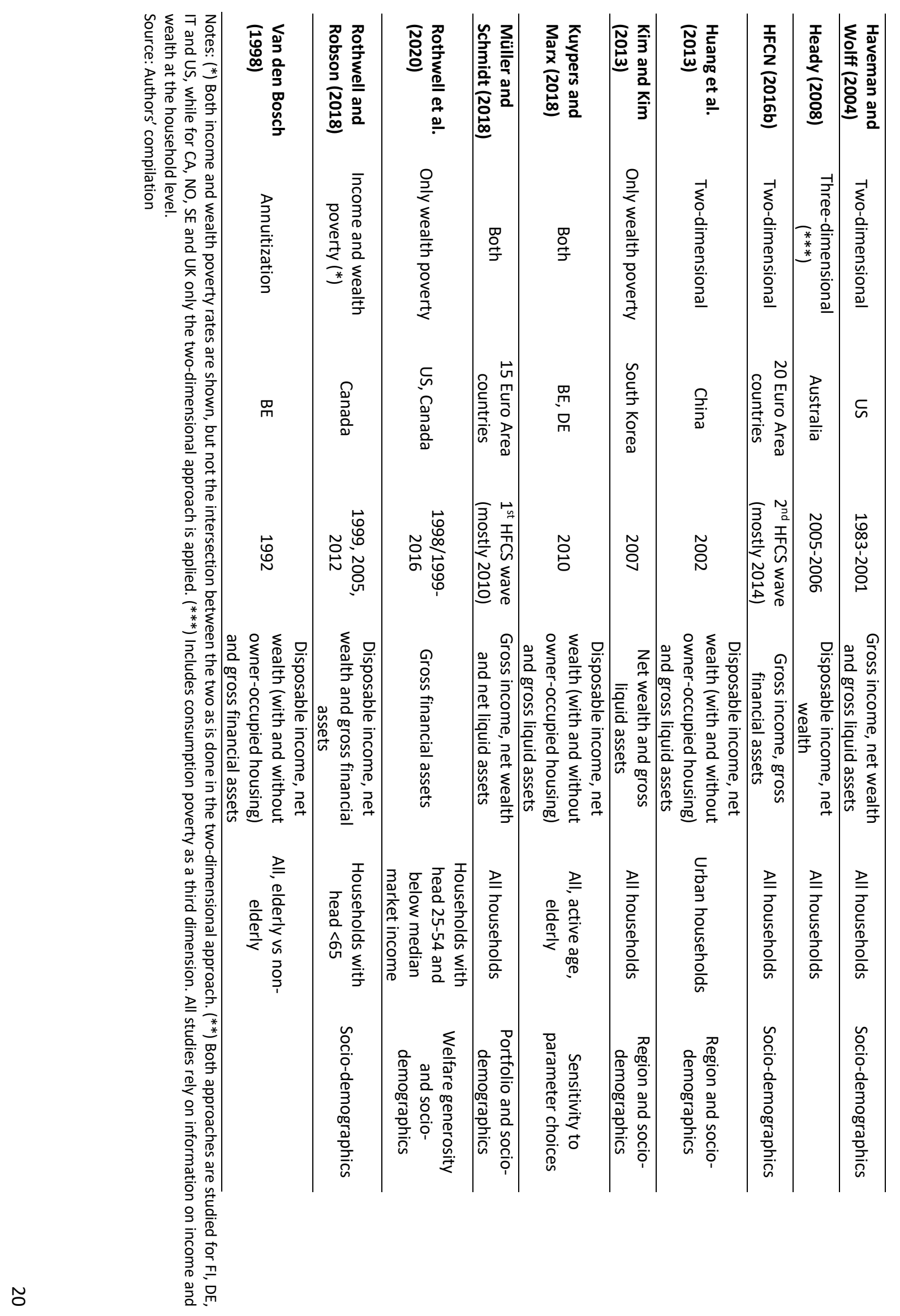


Table 2. Poverty rates, total population and by age group

\begin{tabular}{|c|c|c|c|c|c|c|c|}
\hline \multirow[t]{2}{*}{ Country } & \multirow[t]{2}{*}{ Age group } & \multirow{2}{*}{$\begin{array}{l}\text { Income } \\
\text { poverty }\end{array}$} & \multirow{2}{*}{$\begin{array}{c}\text { Income + } \\
\text { annuitized net } \\
\text { wealth } \\
\text { poverty (same } \\
\text { poverty line) }\end{array}$} & \multirow{2}{*}{$\begin{array}{c}\text { Income + } \\
\text { annuitized net } \\
\text { wealth poverty } \\
\text { (adapted } \\
\text { poverty line) }\end{array}$} & \multicolumn{3}{|c|}{ Multidimensional poverty } \\
\hline & & & & & $\begin{array}{c}\text { Only income } \\
\text { poor }\end{array}$ & $\begin{array}{c}\text { Only net } \\
\text { wealth poor }\end{array}$ & $\begin{array}{l}\text { Twice } \\
\text { poor }\end{array}$ \\
\hline \multirow{4}{*}{ Austria } & Total & $7.4 \%$ & $6.3 \%$ & $9.3 \%$ & $4.7 \%$ & $9.4 \%$ & $2.7 \%$ \\
\hline & Children & $7.5 \%$ & $7.3 \%$ & $11.5 \%$ & $4.3 \%$ & $11.0 \%$ & $3.2 \%$ \\
\hline & Active age & $7.2 \%$ & $6.7 \%$ & $9.3 \%$ & $4.2 \%$ & $9.1 \%$ & $3.1 \%$ \\
\hline & Elderly & $7.8 \%$ & $3.9 \%$ & $7.2 \%$ & $6.6 \%$ & $8.7 \%$ & $1.2 \%$ \\
\hline \multirow{4}{*}{ Belgium } & Total & $14.3 \%$ & $12.7 \%$ & $16.3 \%$ & $6.8 \%$ & $11.4 \%$ & $7.5 \%$ \\
\hline & Children & $17.8 \%$ & $15.7 \%$ & $20.5 \%$ & $7.6 \%$ & $14.3 \%$ & $10.2 \%$ \\
\hline & Active age & $14.0 \%$ & $13.2 \%$ & $16.4 \%$ & $6.3 \%$ & $11.3 \%$ & $7.7 \%$ \\
\hline & Elderly & $10.9 \%$ & $6.6 \%$ & $10.3 \%$ & $7.5 \%$ & $8.3 \%$ & $3.4 \%$ \\
\hline \multirow{4}{*}{ Cyprus } & Total & $18.5 \%$ & $14.6 \%$ & $21.0 \%$ & $11.5 \%$ & $9.1 \%$ & $7.0 \%$ \\
\hline & Children & $20.9 \%$ & $17.1 \%$ & $23.6 \%$ & $11.2 \%$ & $9.1 \%$ & $9.7 \%$ \\
\hline & Active age & $17.4 \%$ & $14.0 \%$ & $19.9 \%$ & $12.0 \%$ & $8.2 \%$ & $5.4 \%$ \\
\hline & Elderly & $20.3 \%$ & $13.7 \%$ & $21.9 \%$ & $9.2 \%$ & $13.4 \%$ & $11.1 \%$ \\
\hline \multirow{4}{*}{ Estonia } & Total & $26.5 \%$ & $22.8 \%$ & $25.7 \%$ & $14.6 \%$ & $13.4 \%$ & $12.0 \%$ \\
\hline & Children & $25.5 \%$ & $24.4 \%$ & $26.3 \%$ & $13.1 \%$ & $13.0 \%$ & $12.4 \%$ \\
\hline & Active age & $23.8 \%$ & $21.6 \%$ & $23.9 \%$ & $12.4 \%$ & $14.7 \%$ & $11.4 \%$ \\
\hline & Elderly & $37.9 \%$ & $25.6 \%$ & $31.7 \%$ & $24.4 \%$ & $8.6 \%$ & $13.5 \%$ \\
\hline \multirow{4}{*}{ Finland } & Total & $7.8 \%$ & $7.8 \%$ & $8.4 \%$ & $2.9 \%$ & $33.5 \%$ & $5.0 \%$ \\
\hline & Children & $8.0 \%$ & $8.5 \%$ & $9.3 \%$ & $2.7 \%$ & $37.6 \%$ & $5.3 \%$ \\
\hline & Active age & $8.4 \%$ & $8.6 \%$ & $9.1 \%$ & $2.8 \%$ & $35.4 \%$ & $5.6 \%$ \\
\hline & Elderly & $5.6 \%$ & $4.1 \%$ & $4.8 \%$ & $3.4 \%$ & $22.2 \%$ & $2.2 \%$ \\
\hline \multirow{4}{*}{ France } & Total & $10.2 \%$ & $9.6 \%$ & $10.4 \%$ & $6.8 \%$ & $14.6 \%$ & $3.4 \%$ \\
\hline & Children & $11.5 \%$ & $10.6 \%$ & $11.7 \%$ & $7.0 \%$ & $19.1 \%$ & $4.5 \%$ \\
\hline & Active age & $11.1 \%$ & $10.5 \%$ & $11.3 \%$ & $7.4 \%$ & $14.6 \%$ & $3.6 \%$ \\
\hline & Elderly & $4.9 \%$ & $4.8 \%$ & $5.0 \%$ & $3.9 \%$ & $8.4 \%$ & $1.0 \%$ \\
\hline \multirow{4}{*}{ Germany } & Total & $13.4 \%$ & $12.4 \%$ & $14.4 \%$ & $6.5 \%$ & $19.6 \%$ & $6.9 \%$ \\
\hline & Children & $12.6 \%$ & $12.2 \%$ & $14.4 \%$ & $4.5 \%$ & $27.1 \%$ & $8.2 \%$ \\
\hline & Active age & $11.7 \%$ & $11.2 \%$ & $13.1 \%$ & $5.9 \%$ & $21.0 \%$ & $5.8 \%$ \\
\hline & Elderly & $19.9 \%$ & $16.5 \%$ & $18.5 \%$ & $10.5 \%$ & $8.3 \%$ & $9.4 \%$ \\
\hline \multirow{4}{*}{ Greece } & Total & $15.9 \%$ & $14.5 \%$ & $15.8 \%$ & $8.2 \%$ & $20.3 \%$ & $7.7 \%$ \\
\hline & Children & $19.3 \%$ & $19.1 \%$ & $20.6 \%$ & $8.9 \%$ & $17.2 \%$ & $10.4 \%$ \\
\hline & Active age & $17.2 \%$ & $15.7 \%$ & $17.2 \%$ & $9.1 \%$ & $19.6 \%$ & $8.2 \%$ \\
\hline & Elderly & $8.2 \%$ & $5.8 \%$ & $6.3 \%$ & $4.5 \%$ & $25.9 \%$ & $3.8 \%$ \\
\hline \multirow{4}{*}{ Hungary } & Total & $17.4 \%$ & $15.5 \%$ & $18.2 \%$ & $9.5 \%$ & $18.6 \%$ & $7.9 \%$ \\
\hline & Children & $21.3 \%$ & $19.7 \%$ & $22.6 \%$ & $10.5 \%$ & $16.2 \%$ & $10.7 \%$ \\
\hline & Active age & $18.0 \%$ & $16.1 \%$ & $18.4 \%$ & $10.4 \%$ & $16.3 \%$ & $7.7 \%$ \\
\hline & Elderly & $10.8 \%$ & $8.7 \%$ & $13.1 \%$ & $4.9 \%$ & $30.4 \%$ & $5.9 \%$ \\
\hline \multirow{2}{*}{ Ireland } & Total & $22.6 \%$ & $20.0 \%$ & $23.9 \%$ & $11.9 \%$ & $15.0 \%$ & $10.7 \%$ \\
\hline & Children & $27.7 \%$ & $26.2 \%$ & $31.0 \%$ & $13.0 \%$ & $18.0 \%$ & $14.7 \%$ \\
\hline
\end{tabular}




\begin{tabular}{|c|c|c|c|c|c|c|c|}
\hline & Active age & $22.3 \%$ & $20.5 \%$ & $23.7 \%$ & $11.6 \%$ & $15.2 \%$ & $10.7 \%$ \\
\hline & Elderly & $16.4 \%$ & $7.9 \%$ & $14.1 \%$ & $11.9 \%$ & $9.4 \%$ & $4.5 \%$ \\
\hline \multirow{4}{*}{ Italy } & Total & $19.5 \%$ & $17.9 \%$ & $19.8 \%$ & $9.5 \%$ & $8.6 \%$ & $10.0 \%$ \\
\hline & Children & $24.3 \%$ & $22.3 \%$ & $24.6 \%$ & $10.9 \%$ & $11.3 \%$ & $13.5 \%$ \\
\hline & Active age & $20.5 \%$ & $19.2 \%$ & $21.1 \%$ & $10.1 \%$ & $8.2 \%$ & $10.4 \%$ \\
\hline & Elderly & $12.3 \%$ & $9.8 \%$ & $11.5 \%$ & $6.4 \%$ & $7.8 \%$ & $5.9 \%$ \\
\hline \multirow{4}{*}{ Luxembourg } & Total & $12.8 \%$ & $9.5 \%$ & $17.7 \%$ & $8.2 \%$ & $9.3 \%$ & $4.6 \%$ \\
\hline & Children & $15.1 \%$ & $10.9 \%$ & $22.2 \%$ & $8.6 \%$ & $14.3 \%$ & $6.5 \%$ \\
\hline & Active age & $13.1 \%$ & $10.1 \%$ & $18.6 \%$ & $8.5 \%$ & $8.8 \%$ & $4.7 \%$ \\
\hline & Elderly & $7.2 \%$ & $4.5 \%$ & $5.7 \%$ & $5.9 \%$ & $4.3 \%$ & $1.4 \%$ \\
\hline \multirow{4}{*}{ Poland } & Total & $16.4 \%$ & $12.7 \%$ & $16.2 \%$ & $10.0 \%$ & $21.8 \%$ & $6.5 \%$ \\
\hline & Children & $15.6 \%$ & $11.6 \%$ & $15.0 \%$ & $9.2 \%$ & $22.9 \%$ & $6.3 \%$ \\
\hline & Active age & $17.3 \%$ & $13.3 \%$ & $16.9 \%$ & $10.8 \%$ & $19.8 \%$ & $6.4 \%$ \\
\hline & Elderly & $13.4 \%$ & $10.9 \%$ & $14.5 \%$ & $6.7 \%$ & $30.3 \%$ & $6.7 \%$ \\
\hline \multirow{4}{*}{ Portugal } & Total & $17.9 \%$ & $15.3 \%$ & $19.0 \%$ & $8.6 \%$ & $14.5 \%$ & $9.4 \%$ \\
\hline & Children & $23.7 \%$ & $21.3 \%$ & $25.6 \%$ & $9.9 \%$ & $14.9 \%$ & $13.8 \%$ \\
\hline & Active age & $18.4 \%$ & $15.8 \%$ & $19.7 \%$ & $9.1 \%$ & $14.0 \%$ & $9.3 \%$ \\
\hline & Elderly & $10.6 \%$ & $7.7 \%$ & $10.2 \%$ & $5.4 \%$ & $15.9 \%$ & $5.2 \%$ \\
\hline \multirow{4}{*}{$\begin{array}{c}\text { Slovak } \\
\text { Republic }\end{array}$} & Total & $14.8 \%$ & $14.5 \%$ & $15.5 \%$ & $5.8 \%$ & $18.3 \%$ & $9.1 \%$ \\
\hline & Children & $20.5 \%$ & $19.5 \%$ & $20.3 \%$ & $7.3 \%$ & $16.6 \%$ & $13.2 \%$ \\
\hline & Active age & $13.4 \%$ & $13.4 \%$ & $14.2 \%$ & $5.3 \%$ & $18.0 \%$ & $8.1 \%$ \\
\hline & Elderly & $14.5 \%$ & $13.7 \%$ & $15.5 \%$ & $6.2 \%$ & $22.2 \%$ & $8.3 \%$ \\
\hline \multirow{4}{*}{ Slovenia } & Total & $8.3 \%$ & $6.4 \%$ & $9.5 \%$ & $4.5 \%$ & $19.6 \%$ & $3.9 \%$ \\
\hline & Children & $2.1 \%$ & $1.6 \%$ & $2.8 \%$ & $1.2 \%$ & $21.8 \%$ & $0.9 \%$ \\
\hline & Active age & $8.4 \%$ & $6.5 \%$ & $9.8 \%$ & $4.2 \%$ & $18.9 \%$ & $4.2 \%$ \\
\hline & Elderly & $14.9 \%$ & $11.1 \%$ & $15.2 \%$ & $8.9 \%$ & $20.0 \%$ & $6.0 \%$ \\
\hline \multirow{4}{*}{ Spain } & Total & $21.0 \%$ & $17.4 \%$ & $24.0 \%$ & $15.4 \%$ & $7.6 \%$ & $5.6 \%$ \\
\hline & Children & $30.7 \%$ & $24.9 \%$ & $33.5 \%$ & $22.9 \%$ & $4.5 \%$ & $7.7 \%$ \\
\hline & Active age & $22.0 \%$ & $18.4 \%$ & $24.3 \%$ & $16.1 \%$ & $6.7 \%$ & $5.9 \%$ \\
\hline & Elderly & $5.4 \%$ & $4.1 \%$ & $11.6 \%$ & $3.7 \%$ & $15.0 \%$ & $1.6 \%$ \\
\hline
\end{tabular}

Source: Authors' calculations based on HFCS wave 2 data and EUROMOD simulations. 
Table 3. Socio-demographic profile of joint income-wealth poor (pooled across countries)

\begin{tabular}{|c|c|c|c|c|c|c|}
\hline \multirow{2}{*}{ Age (ref:55-74 years) } & \multicolumn{2}{|c|}{$\begin{array}{c}\text { Annuitized poor } \\
\text { (adjusted poverty } \\
\text { line) }\end{array}$} & \multicolumn{2}{|c|}{ Twice poor } & \multicolumn{2}{|c|}{ Income poor } \\
\hline & & & & & & \\
\hline $16-34$ years & 1.58 & $* * *$ & 1.27 & $* * *$ & 1.28 & $* * *$ \\
\hline $35-54$ years & 1.46 & $* * *$ & 1.29 & $* * *$ & 1.26 & $* * *$ \\
\hline $75+$ years & 0.66 & $* * *$ & 0.65 & $* * *$ & 0.83 & $* * *$ \\
\hline Gender (ref: male) & 1.55 & $* * *$ & 1.58 & $* * *$ & 1.48 & $* * *$ \\
\hline \multicolumn{7}{|c|}{ Educational attainment (ref: tertiary) } \\
\hline No or primary & 5.37 & $* * *$ & 7.33 & $* * *$ & 3.97 & $* * *$ \\
\hline Secondary & 3.13 & $* * *$ & 3.70 & $* * *$ & 2.70 & $* * *$ \\
\hline \multicolumn{7}{|c|}{ Labour market status (ref: employee) } \\
\hline Self-employed & 1.43 & $* * *$ & 0.66 & $* * *$ & 2.21 & $* * *$ \\
\hline Unemployed & 8.75 & $* * *$ & 8.27 & $* * *$ & 8.90 & $* * *$ \\
\hline Retired & 2.18 & $* * *$ & 2.31 & $* * *$ & 2.25 & $* * *$ \\
\hline Inactive & 6.19 & $* * *$ & 6.33 & $* * *$ & 6.34 & $* * *$ \\
\hline \multicolumn{7}{|c|}{ Household type (ref: couple) } \\
\hline Single & 2.11 & $* * *$ & 2.44 & $* * *$ & 2.18 & $* * *$ \\
\hline Single parent & 1.63 & $* * *$ & 2.29 & $* * *$ & 1.68 & $* * *$ \\
\hline Couple with children & 1.55 & $* * *$ & 1.88 & $* * *$ & 1.67 & $* * *$ \\
\hline Other & 1.95 & $* * *$ & 2.37 & $* * *$ & 2.02 & $* * *$ \\
\hline \multicolumn{7}{|c|}{ Tenure status (ref: outright owner) } \\
\hline Owner with mortgage & 0.99 & & 1.08 & & 0.87 & $* * *$ \\
\hline Tennant/free user & 2.16 & $* * *$ & 3.53 & $* * *$ & 1.79 & $* * *$ \\
\hline \multicolumn{7}{|l|}{ Country (ref: Austria) } \\
\hline Belgium & 2.34 & $* * *$ & 3.46 & $* * *$ & 2.46 & $* * *$ \\
\hline Cyprus & 2.80 & $* * *$ & 2.99 & $* * *$ & 2.97 & $* * *$ \\
\hline Estonia & 4.61 & $* * *$ & 7.25 & $* * *$ & 6.01 & $* * *$ \\
\hline Finland & 0.80 & $* * *$ & 1.76 & $* * *$ & 0.96 & \\
\hline France & 0.86 & $* *$ & 0.84 & $*$ & 1.13 & $* *$ \\
\hline Germany & 1.63 & $* * *$ & 2.47 & $* * *$ & 2.00 & $* * *$ \\
\hline Greece & 1.75 & $* * *$ & 3.35 & $* * *$ & 2.14 & $* * *$ \\
\hline Hungary & 2.99 & $* * *$ & 4.96 & $* * *$ & 3.43 & $* * *$ \\
\hline Ireland & 3.30 & $* * *$ & 4.26 & $* * *$ & 3.81 & $* * *$ \\
\hline Italy & 2.33 & $* * *$ & 4.01 & $* * *$ & 2.79 & $* * *$ \\
\hline Luxembourg & 2.30 & $* * *$ & 1.67 & $* * *$ & 1.98 & $* * *$ \\
\hline Poland & 2.19 & $* * *$ & 3.19 & $* * *$ & 2.75 & $* * *$ \\
\hline Portugal & 1.77 & $* * *$ & 2.80 & $* * *$ & 2.20 & $* * *$ \\
\hline Slovak Republic & 2.25 & $* * *$ & 6.24 & $* * *$ & 2.51 & $* * *$ \\
\hline Slovenia & 1.06 & & 1.67 & $* * *$ & 1.11 & \\
\hline Spain & 2.64 & $* * *$ & 1.48 & $* * *$ & 2.67 & $* * *$ \\
\hline Constant & 0.01 & $* * *$ & 0.00 & $* * *$ & 0.01 & $* * *$ \\
\hline$R^{2}$ & \multicolumn{2}{|c|}{0.1883} & \multicolumn{2}{|c|}{0.2371} & \multicolumn{2}{|c|}{0.1743} \\
\hline
\end{tabular}

Notes: Odds ratios are shown. ${ }^{* * *}$ significant at $1 \%,{ }^{* *}$ significant at $5 \%,{ }^{*}$ significant at $10 \%$

Source: Authors' calculations based on HFCS wave 2 data and EUROMOD simulations. 
Table 4. Reason for being joint income-wealth poor

\begin{tabular}{|c|c|c|c|c|c|c|c|c|}
\hline & \multicolumn{4}{|c|}{ Annuitized poor (adapted poverty line) } & \multicolumn{4}{|c|}{ Twice poor } \\
\hline & All & $\begin{array}{c}\text { Non- } \\
\text { over- } \\
\text { indebted }\end{array}$ & $\begin{array}{c}\text { Over- } \\
\text { indebted } \\
\text { asset- } \\
\text { poor }\end{array}$ & $\begin{array}{c}\text { Over- } \\
\text { indebted } \\
\text { asset-non- } \\
\text { poor }\end{array}$ & All & $\begin{array}{c}\text { Non- } \\
\text { over- } \\
\text { indebted }\end{array}$ & $\begin{array}{c}\text { Over- } \\
\text { indebted } \\
\text { asset- } \\
\text { poor }\end{array}$ & $\begin{array}{c}\text { Over- } \\
\text { indebted } \\
\text { asset-non- } \\
\text { poor }\end{array}$ \\
\hline Austria & $9.3 \%$ & $7.2 \%$ & $1.9 \%$ & $0.2 \%$ & $2.7 \%$ & $1.7 \%$ & $0.8 \%$ & $0.2 \%$ \\
\hline Belgium & $16.3 \%$ & $14.3 \%$ & $1.8 \%$ & $0.1 \%$ & $7.5 \%$ & $6.0 \%$ & $1.1 \%$ & $0.4 \%$ \\
\hline Cyprus & $21.0 \%$ & $15.0 \%$ & $4.4 \%$ & $1.6 \%$ & $7.0 \%$ & $3.4 \%$ & $1.0 \%$ & $2.7 \%$ \\
\hline Estonia & $25.7 \%$ & $22.5 \%$ & $3.1 \%$ & $0.1 \%$ & $12.0 \%$ & $8.9 \%$ & $2.8 \%$ & $0.3 \%$ \\
\hline Finland & $8.4 \%$ & $5.2 \%$ & $2.5 \%$ & $0.7 \%$ & $5.0 \%$ & $2.6 \%$ & $1.4 \%$ & $1.0 \%$ \\
\hline France & $10.4 \%$ & $9.2 \%$ & $0.7 \%$ & $0.5 \%$ & $3.4 \%$ & $2.4 \%$ & $0.3 \%$ & $0.6 \%$ \\
\hline Germany & $14.4 \%$ & $11.0 \%$ & $2.8 \%$ & $0.5 \%$ & $6.9 \%$ & $4.2 \%$ & $2.2 \%$ & $0.4 \%$ \\
\hline Greece & $15.8 \%$ & $12.0 \%$ & $3.7 \%$ & $0.1 \%$ & $7.7 \%$ & $4.4 \%$ & $2.8 \%$ & $0.5 \%$ \\
\hline Hungary & $18.2 \%$ & $12.8 \%$ & $5.0 \%$ & $0.4 \%$ & $7.9 \%$ & $3.6 \%$ & $3.7 \%$ & $0.7 \%$ \\
\hline Ireland & $23.9 \%$ & $19.3 \%$ & $4.2 \%$ & $0.3 \%$ & $10.7 \%$ & $6.3 \%$ & $3.4 \%$ & $1.0 \%$ \\
\hline Italy & $19.8 \%$ & $16.7 \%$ & $3.1 \%$ & $0.0 \%$ & $10.0 \%$ & $6.9 \%$ & $2.5 \%$ & $0.5 \%$ \\
\hline Luxembourg & $17.7 \%$ & $14.3 \%$ & $2.9 \%$ & $0.5 \%$ & $4.6 \%$ & $3.1 \%$ & $0.8 \%$ & $0.7 \%$ \\
\hline Poland & $16.2 \%$ & $12.3 \%$ & $3.9 \%$ & $0.0 \%$ & $6.5 \%$ & $3.0 \%$ & $3.2 \%$ & $0.2 \%$ \\
\hline Portugal & $19.0 \%$ & $15.6 \%$ & $3.2 \%$ & $0.2 \%$ & $9.4 \%$ & $6.6 \%$ & $2.4 \%$ & $0.4 \%$ \\
\hline Slovak Republic & $15.5 \%$ & $8.9 \%$ & $6.6 \%$ & $0.0 \%$ & $9.1 \%$ & $2.9 \%$ & $5.8 \%$ & $0.4 \%$ \\
\hline Slovenia & $9.5 \%$ & $7.4 \%$ & $1.9 \%$ & $0.2 \%$ & $3.9 \%$ & $2.4 \%$ & $1.3 \%$ & $0.2 \%$ \\
\hline Spain & $24.0 \%$ & $21.0 \%$ & $2.4 \%$ & $0.6 \%$ & $5.6 \%$ & $3.7 \%$ & $1.0 \%$ & $0.8 \%$ \\
\hline
\end{tabular}

Source: Authors' calculations based on HFCS wave 2 data and EUROMOD simulations. 
Table 5. Cross-country decomposition of joint income-wealth poverty (base country: Austria)

\begin{tabular}{|c|c|c|c|c|c|c|}
\hline & \multicolumn{3}{|c|}{$\begin{array}{c}\text { Annuitized poor (adjusted } \\
\text { poverty line) }\end{array}$} & \multicolumn{3}{|c|}{ Twice poor } \\
\hline & absolute & & relative & absolute & & relative \\
\hline \multicolumn{7}{|l|}{ Belgium } \\
\hline Raw difference & 7.01 & $* * *$ & & 4.80 & $* * *$ & \\
\hline Explained difference & -0.38 & & $-5 \%$ & 0.91 & $*$ & $19 \%$ \\
\hline Age & -0.01 & & $0 \%$ & 0.06 & & $1 \%$ \\
\hline Gender & -0.16 & $* *$ & $-2 \%$ & 0.02 & & $0 \%$ \\
\hline Education & -0.11 & & $-2 \%$ & 1.24 & $*$ & $26 \%$ \\
\hline Labour market status & 2.23 & $* * *$ & $32 \%$ & 1.23 & $* * *$ & $26 \%$ \\
\hline Household type & 0.10 & & $1 \%$ & 0.08 & & $2 \%$ \\
\hline Tenure status & -2.42 & $* * *$ & $-35 \%$ & -1.72 & $* * *$ & $-36 \%$ \\
\hline \multicolumn{7}{|l|}{ Cyprus } \\
\hline Raw difference & 11.70 & $* * *$ & & 4.31 & $* * *$ & \\
\hline Explained difference & -0.06 & & $-1 \%$ & 0.40 & & $9 \%$ \\
\hline Age & 0.45 & & $4 \%$ & -0.22 & & $-5 \%$ \\
\hline Gender & 0.09 & $*$ & $1 \%$ & -0.03 & & $-1 \%$ \\
\hline Education & 0.62 & & $5 \%$ & 3.16 & & $73 \%$ \\
\hline Labour market status & 2.51 & $* * *$ & $21 \%$ & 1.08 & $* * *$ & $25 \%$ \\
\hline Household type & -0.21 & & $-2 \%$ & -0.38 & $* *$ & $-9 \%$ \\
\hline Tenure status & -3.53 & $* * *$ & $-30 \%$ & -3.20 & $* * *$ & $-74 \%$ \\
\hline \multicolumn{7}{|l|}{ Estonia } \\
\hline Raw difference & 16.40 & $* * *$ & & 9.23 & $* * *$ & \\
\hline Explained difference & -0.53 & & $-3 \%$ & -0.16 & & $-2 \%$ \\
\hline Age & 0.58 & & $4 \%$ & 0.06 & & $1 \%$ \\
\hline Gender & 0.09 & & $1 \%$ & 0.00 & & $0 \%$ \\
\hline Education & -0.17 & & $-1 \%$ & 0.36 & $*$ & $4 \%$ \\
\hline Labour market status & 1.43 & $* * *$ & $9 \%$ & 1.11 & $* * *$ & $12 \%$ \\
\hline Household type & 0.37 & & $2 \%$ & 0.14 & & $2 \%$ \\
\hline Tenure status & -2.84 & $* * *$ & $-17 \%$ & -1.83 & $* * *$ & $-20 \%$ \\
\hline \multicolumn{7}{|l|}{ Finland } \\
\hline Raw difference & -0.84 & & & 2.23 & $* * *$ & \\
\hline Explained difference & 0.35 & & $-42 \%$ & 0.86 & $* * *$ & $38 \%$ \\
\hline Age & 0.38 & & $-45 \%$ & -0.04 & & $-2 \%$ \\
\hline Gender & 0.02 & & $-3 \%$ & 0.00 & & $0 \%$ \\
\hline Education & -0.24 & & $28 \%$ & 0.36 & $* *$ & $16 \%$ \\
\hline Labour market status & 2.25 & $* * *$ & $-270 \%$ & 1.61 & $* * *$ & $72 \%$ \\
\hline Household type & 0.15 & & $-18 \%$ & 0.18 & $* *$ & $8 \%$ \\
\hline Tenure status & -2.21 & $* * *$ & $265 \%$ & -1.25 & $* * *$ & $-56 \%$ \\
\hline \multicolumn{7}{|l|}{ France } \\
\hline Raw difference & 1.15 & & & 0.69 & $*$ & \\
\hline Explained difference & 2.78 & $* *$ & $242 \%$ & 2.68 & $* *$ & $391 \%$ \\
\hline Age & 0.39 & & $34 \%$ & -0.04 & & $-6 \%$ \\
\hline Gender & 0.08 & & $7 \%$ & -0.03 & & $-4 \%$ \\
\hline Education & 0.38 & & $33 \%$ & 2.44 & $*$ & $356 \%$ \\
\hline Labour market status & 2.41 & $* * *$ & $210 \%$ & 1.31 & $* * *$ & $191 \%$ \\
\hline Household type & 0.12 & & $10 \%$ & -0.11 & & $-16 \%$ \\
\hline
\end{tabular}




\begin{tabular}{|c|c|c|c|c|c|c|}
\hline Tenure status & -0.60 & $* * *$ & $-53 \%$ & -0.89 & $*$ & $-129 \%$ \\
\hline \multicolumn{7}{|l|}{ Germany } \\
\hline Raw difference & 5.09 & $* * *$ & & 4.18 & $* * *$ & \\
\hline Explained difference & 1.06 & $* * *$ & $21 \%$ & 1.21 & $* * *$ & $29 \%$ \\
\hline Age & 0.38 & & $7 \%$ & -0.01 & & $0 \%$ \\
\hline Gender & 0.02 & & $0 \%$ & -0.01 & & $0 \%$ \\
\hline Education & -0.06 & & $-1 \%$ & 0.59 & $* *$ & $14 \%$ \\
\hline Labour market status & -0.02 & & $0 \%$ & 0.35 & $*$ & $8 \%$ \\
\hline Household type & 0.13 & & $3 \%$ & -0.03 & & $-1 \%$ \\
\hline Tenure status & 0.62 & $* * *$ & $12 \%$ & 0.32 & $* * *$ & $8 \%$ \\
\hline \multicolumn{7}{|l|}{ Greece } \\
\hline Raw difference & 6.56 & $* * *$ & & 5.02 & $* * *$ & \\
\hline Explained difference & 1.18 & & $18 \%$ & 1.26 & & $25 \%$ \\
\hline Age & 0.28 & & $4 \%$ & 0.02 & & $0 \%$ \\
\hline Gender & -0.18 & $* *$ & $-3 \%$ & 0.02 & & $0 \%$ \\
\hline Education & 0.68 & & $10 \%$ & 2.88 & & $57 \%$ \\
\hline Labour market status & 2.73 & $* * *$ & $42 \%$ & 0.86 & $* * *$ & $17 \%$ \\
\hline Household type & 0.02 & & $0 \%$ & -0.16 & & $-3 \%$ \\
\hline Tenure status & -2.35 & $* * *$ & $-36 \%$ & -2.36 & $* *$ & $-47 \%$ \\
\hline \multicolumn{7}{|l|}{ Hungary } \\
\hline Raw difference & 8.97 & $* * *$ & & 5.19 & $* * *$ & \\
\hline Explained difference & -2.10 & $* * *$ & $-23 \%$ & -1.24 & $* * *$ & $-24 \%$ \\
\hline Age & 0.17 & & $2 \%$ & 0.07 & & $1 \%$ \\
\hline Gender & 0.11 & $*$ & $1 \%$ & -0.01 & & $0 \%$ \\
\hline Education & -0.15 & & $-2 \%$ & 0.15 & & $3 \%$ \\
\hline Labour market status & 0.88 & $* *$ & $10 \%$ & 0.58 & $* * *$ & $11 \%$ \\
\hline Household type & 0.19 & & $2 \%$ & -0.02 & & $0 \%$ \\
\hline Tenure status & -3.29 & $* * *$ & $-37 \%$ & -2.01 & $* * *$ & $-39 \%$ \\
\hline \multicolumn{7}{|l|}{ Ireland } \\
\hline Raw difference & 14.62 & $* * *$ & & 7.96 & $* * *$ & \\
\hline Explained difference & 1.51 & & $10 \%$ & 1.79 & $* *$ & $22 \%$ \\
\hline Age & 0.50 & & $3 \%$ & 0.04 & & $0 \%$ \\
\hline Gender & 0.07 & & $0 \%$ & -0.03 & & $0 \%$ \\
\hline Education & 0.23 & & $2 \%$ & 2.00 & $*$ & $25 \%$ \\
\hline Labour market status & 3.60 & $* * *$ & $25 \%$ & 1.72 & $* * *$ & $22 \%$ \\
\hline Household type & -0.16 & & $-1 \%$ & -0.08 & & $-1 \%$ \\
\hline Tenure status & -2.74 & $* * *$ & $-19 \%$ & -1.85 & $* * *$ & $-23 \%$ \\
\hline \multicolumn{7}{|l|}{ Italy } \\
\hline Raw difference & 10.52 & $* * *$ & & 7.26 & $* * *$ & \\
\hline Explained difference & 0.46 & & $4 \%$ & 2.09 & & $29 \%$ \\
\hline Age & -0.62 & & $-6 \%$ & -0.08 & & $-1 \%$ \\
\hline Gender & -0.11 & $* *$ & $-1 \%$ & 0.00 & & $0 \%$ \\
\hline Education & 0.87 & & $8 \%$ & 3.13 & $*$ & $43 \%$ \\
\hline Labour market status & 1.71 & $* * *$ & $16 \%$ & 0.96 & $* * *$ & $13 \%$ \\
\hline Household type & 0.19 & & $2 \%$ & -0.02 & & $0 \%$ \\
\hline Tenure status & -1.59 & $* * *$ & $-15 \%$ & -1.90 & $* *$ & $-26 \%$ \\
\hline \multicolumn{7}{|l|}{ Luxembourg } \\
\hline Raw difference & 8.43 & $* * *$ & & 1.90 & $* *$ & \\
\hline
\end{tabular}




\begin{tabular}{|c|c|c|c|c|c|c|}
\hline Explained difference & -0.96 & & $-11 \%$ & 2.19 & & $115 \%$ \\
\hline Age & 0.45 & & $5 \%$ & 0.15 & & $8 \%$ \\
\hline Gender & -0.14 & $* *$ & $-2 \%$ & 0.02 & & $1 \%$ \\
\hline Education & 0.60 & & $7 \%$ & 3.53 & $*$ & $185 \%$ \\
\hline Labour market status & -0.41 & & $-5 \%$ & 0.07 & & $4 \%$ \\
\hline Household type & 0.18 & & $2 \%$ & -0.04 & & $-2 \%$ \\
\hline Tenure status & -1.65 & $* * *$ & $-20 \%$ & -1.54 & $* *$ & $-81 \%$ \\
\hline \multicolumn{7}{|l|}{ Poland } \\
\hline Raw difference & 6.98 & $* * *$ & & 3.73 & $* * *$ & \\
\hline Explained difference & -1.11 & & $-16 \%$ & 0.21 & & $6 \%$ \\
\hline Age & 0.53 & & $8 \%$ & 0.04 & & $1 \%$ \\
\hline Gender & -0.04 & & $-1 \%$ & 0.00 & & $0 \%$ \\
\hline Education & 0.46 & & $7 \%$ & 1.88 & $*$ & $50 \%$ \\
\hline Labour market status & 0.41 & & $6 \%$ & 0.53 & $* * *$ & $14 \%$ \\
\hline Household type & 0.17 & & $2 \%$ & 0.05 & & $1 \%$ \\
\hline Tenure status & -2.65 & $* * *$ & $-38 \%$ & -2.29 & $* * *$ & $-61 \%$ \\
\hline \multicolumn{7}{|l|}{ Portugal } \\
\hline Raw difference & 9.75 & $* * *$ & & 6.65 & $* * *$ & \\
\hline Explained difference & 1.93 & & $20 \%$ & 4.37 & & $66 \%$ \\
\hline Age & 0.14 & & $1 \%$ & -0.04 & & $-1 \%$ \\
\hline Gender & 0.08 & & $1 \%$ & -0.03 & & $0 \%$ \\
\hline Education & 1.80 & & $18 \%$ & 6.72 & & $101 \%$ \\
\hline Labour market status & 2.92 & $* * *$ & $30 \%$ & 1.58 & $* * *$ & $24 \%$ \\
\hline Household type & -0.03 & & $0 \%$ & -0.09 & & $-1 \%$ \\
\hline Tenure status & -2.98 & $* * *$ & $-31 \%$ & -3.78 & $* *$ & $-57 \%$ \\
\hline \multicolumn{7}{|l|}{ Slovak Republic } \\
\hline Raw difference & 6.24 & $* * *$ & & 6.34 & $* * *$ & \\
\hline Explained difference & -1.26 & $* * *$ & $-20 \%$ & -0.86 & $* * *$ & $-14 \%$ \\
\hline Age & 0.78 & $* *$ & $13 \%$ & 0.29 & & $5 \%$ \\
\hline Gender & -0.15 & $* *$ & $-2 \%$ & 0.05 & & $1 \%$ \\
\hline Education & 0.09 & & $1 \%$ & 0.23 & $*$ & $4 \%$ \\
\hline Labour market status & 1.12 & $* *$ & $18 \%$ & 0.77 & $* * *$ & $12 \%$ \\
\hline Household type & 0.33 & & $5 \%$ & 0.02 & & $0 \%$ \\
\hline Tenure status & -3.43 & $* * *$ & $-55 \%$ & -2.23 & $* * *$ & $-35 \%$ \\
\hline \multicolumn{7}{|l|}{ Slovenia } \\
\hline Raw difference & 0.24 & & & 1.15 & $*$ & \\
\hline Explained difference & -0.27 & & $-115 \%$ & -0.15 & & $-13 \%$ \\
\hline Age & 0.13 & & $55 \%$ & 0.13 & & $12 \%$ \\
\hline Gender & 0.05 & & $20 \%$ & 0.00 & & $0 \%$ \\
\hline Education & 0.08 & & $35 \%$ & 0.59 & $* *$ & $51 \%$ \\
\hline Labour market status & 1.35 & $* * *$ & $566 \%$ & 0.47 & $* *$ & $40 \%$ \\
\hline Household type & 0.34 & & $141 \%$ & 0.14 & & $12 \%$ \\
\hline Tenure status & -2.23 & $* * *$ & $-931 \%$ & -1.48 & $* * *$ & $-128 \%$ \\
\hline \multicolumn{7}{|l|}{ Spain } \\
\hline Raw difference & 14.77 & $* * *$ & & 2.86 & $* * *$ & \\
\hline Explained difference & 2.20 & & $15 \%$ & 3.27 & & $114 \%$ \\
\hline Age & -0.14 & & $-1 \%$ & -0.05 & & $-2 \%$ \\
\hline Gender & -0.07 & & $0 \%$ & -0.01 & & $0 \%$ \\
\hline
\end{tabular}




\begin{tabular}{|c|c|c|c|c|c|c|}
\hline Education & 1.32 & & $9 \%$ & 5.64 & & $197 \%$ \\
\hline Labour market status & 5.14 & $* * *$ & $35 \%$ & 2.46 & $* * *$ & $86 \%$ \\
\hline Household type & 0.07 & & $0 \%$ & -0.06 & & $-2 \%$ \\
\hline Tenure status & -4.11 & $* * *$ & $-28 \%$ & -4.72 & $* * *$ & $-165 \%$ \\
\hline
\end{tabular}

Notes: ${ }^{* * *}$ significant at $1 \%,{ }^{* *}$ significant at $5 \%,{ }^{*}$ significant at $10 \%$. The relative column shows the explained differences as a percentage of the raw differences.

Source: Authors' calculations based on HFCS wave 2 data and EUROMOD simulations. 


\section{Appendix 1: Additional tables and figures}

Table A.1. Summary statistics of the distributions of income and wealth and their correlation, 2017

\begin{tabular}{lcccccc}
\hline Country & $\begin{array}{c}\text { Gini } \\
\text { disposable } \\
\text { income }\end{array}$ & $\begin{array}{c}\text { Gini net } \\
\text { wealth }\end{array}$ & $\begin{array}{c}\text { Median net } \\
\text { wealth }(€)\end{array}$ & $\begin{array}{c}\text { Rank } \\
\text { correlation } \\
\text { income-net } \\
\text { wealth }\end{array}$ & $\begin{array}{c}\text { Net wealth } \\
\text { to income } \\
\text { ratio bottom } \\
20 \% \text { active } \\
\text { age }\end{array}$ & $\begin{array}{c}\text { Net wealth } \\
\text { to income } \\
\text { ratio } \\
\text { bottom } \\
\text { 20\%, elderly }\end{array}$ \\
\hline Austria & 0.200 & 0.641 & 186,300 & 0.434 & 5.7 & 7.4 \\
Belgium & 0.250 & 0.589 & 257,800 & 0.466 & 7.2 & 20.9 \\
Cyprus & 0.324 & 0.762 & 228,900 & 0.395 & 18.9 & 24.1 \\
Estonia & 0.401 & 0.678 & 64,300 & 0.387 & 9.8 & 9.5 \\
Finland & 0.233 & 0.676 & 105,500 & 0.415 & 2.4 & 5.9 \\
France & 0.260 & 0.648 & 136,700 & 0.665 & 7.4 & 11.7 \\
Germany & 0.318 & 0.586 & 89,600 & 0.568 & 4.2 & 8.1 \\
Greece & 0.296 & 0.785 & 60,500 & 0.298 & 6.1 & 11.0 \\
Hungary & 0.329 & 0.628 & 41,300 & 0.405 & 12.0 & 16.9 \\
Ireland & 0.331 & 0.599 & 155,000 & 0.377 & 7.8 & 17.6 \\
Italy & 0.340 & 0.599 & 162,700 & 0.565 & 8.9 & 9.7 \\
Luxembourg & 0.296 & 0.731 & 564,700 & 0.598 & 7.5 & 28.9 \\
Poland & 0.333 & 0.698 & 75,400 & 0.187 & 19.6 & 17.7 \\
Portugal & 0.330 & 0.646 & 80,000 & 0.443 & 9.0 & 13.2 \\
Slovak Republic & 0.252 & 0.587 & 60,700 & 0.409 & 6.1 & 11.3 \\
Slovenia & 0.264 & 0.603 & 98,600 & 0.338 & 10.6 & 15.4 \\
Spain & 0.383 & 0.691 & 247,400 & 0.641 & 19.4 & 30.9 \\
\hline
\end{tabular}

Notes: Net wealth to income ratios are calculated for the bottom $20 \%$ of the disposable income distribution. Median net wealth is presented in euros for all countries as the HFCS also covers amounts in euros for Poland and Hungary. Source: Authors' calculations based on HFCS wave 2 data and EUROMOD simulations. 
Table A.2. Poverty rates for total net wealth

\begin{tabular}{|c|c|c|c|c|c|c|c|}
\hline \multirow[t]{2}{*}{ Country } & \multirow[t]{2}{*}{ Age group } & \multirow{2}{*}{$\begin{array}{l}\text { Income } \\
\text { poverty }\end{array}$} & \multirow{2}{*}{$\begin{array}{c}\text { Income + } \\
\text { annuitized net } \\
\text { wealth } \\
\text { poverty (same } \\
\text { poverty line) } \\
\end{array}$} & \multirow{2}{*}{$\begin{array}{c}\text { Income + } \\
\text { annuitized net } \\
\text { wealth poverty } \\
\text { (adapted } \\
\text { poverty line) } \\
\end{array}$} & \multicolumn{3}{|c|}{ Multidimensional poverty } \\
\hline & & & & & $\begin{array}{c}\text { Only income } \\
\text { poor }\end{array}$ & $\begin{array}{c}\text { Only net } \\
\text { wealth poor }\end{array}$ & $\begin{array}{l}\text { Twice } \\
\text { poor }\end{array}$ \\
\hline \multirow{4}{*}{ Austria } & Total & $7.4 \%$ & $5.2 \%$ & $13.1 \%$ & $4.8 \%$ & $7.7 \%$ & $2.6 \%$ \\
\hline & Children & $7.5 \%$ & $6.6 \%$ & $18.2 \%$ & $4.3 \%$ & $9.4 \%$ & $3.2 \%$ \\
\hline & Active age & $7.2 \%$ & $5.5 \%$ & $12.4 \%$ & $4.3 \%$ & $7.6 \%$ & $2.9 \%$ \\
\hline & Elderly & $7.8 \%$ & $2.7 \%$ & $11.0 \%$ & $6.9 \%$ & $6.7 \%$ & $0.8 \%$ \\
\hline \multirow{4}{*}{ Belgium } & Total & $14.3 \%$ & $9.9 \%$ & $16.4 \%$ & $8.5 \%$ & $4.6 \%$ & $5.7 \%$ \\
\hline & Children & $17.8 \%$ & $13.7 \%$ & $20.6 \%$ & $10.0 \%$ & $4.7 \%$ & $7.7 \%$ \\
\hline & Active age & $14.0 \%$ & $10.6 \%$ & $16.7 \%$ & $7.8 \%$ & $4.4 \%$ & $6.2 \%$ \\
\hline & Elderly & $10.9 \%$ & $2.4 \%$ & $9.3 \%$ & $9.5 \%$ & $5.0 \%$ & $1.5 \%$ \\
\hline \multirow{4}{*}{ Cyprus } & Total & $18.5 \%$ & $8.3 \%$ & $19.3 \%$ & $15.5 \%$ & $5.2 \%$ & $2.9 \%$ \\
\hline & Children & $20.9 \%$ & $10.5 \%$ & $22.6 \%$ & $17.7 \%$ & $4.9 \%$ & $3.2 \%$ \\
\hline & Active age & $17.4 \%$ & $7.7 \%$ & $18.9 \%$ & $15.3 \%$ & $5.1 \%$ & $2.1 \%$ \\
\hline & Elderly & $20.3 \%$ & $8.1 \%$ & $16.2 \%$ & $13.3 \%$ & $6.4 \%$ & $6.9 \%$ \\
\hline \multirow{4}{*}{ Estonia } & Total & $26.6 \%$ & $15.9 \%$ & $23.7 \%$ & $21.3 \%$ & $4.9 \%$ & $5.2 \%$ \\
\hline & Children & $25.5 \%$ & $18.9 \%$ & $26.0 \%$ & $20.1 \%$ & $5.3 \%$ & $5.4 \%$ \\
\hline & Active age & $23.9 \%$ & $16.2 \%$ & $23.5 \%$ & $18.4 \%$ & $5.5 \%$ & $5.4 \%$ \\
\hline & Elderly & $38.1 \%$ & $11.4 \%$ & $22.2 \%$ & $33.8 \%$ & $2.0 \%$ & $4.3 \%$ \\
\hline \multirow{4}{*}{ Finland } & Total & $7.8 \%$ & $5.4 \%$ & $11.8 \%$ & $4.8 \%$ & $18.0 \%$ & $3.0 \%$ \\
\hline & Children & $8.0 \%$ & $5.5 \%$ & $13.5 \%$ & $6.2 \%$ & $19.3 \%$ & $1.8 \%$ \\
\hline & Active age & $8.4 \%$ & $6.7 \%$ & $13.3 \%$ & $4.3 \%$ & $20.2 \%$ & $4.1 \%$ \\
\hline & Elderly & $5.6 \%$ & $1.0 \%$ & $4.6 \%$ & $5.0 \%$ & $8.6 \%$ & $0.6 \%$ \\
\hline \multirow{4}{*}{ France } & Total & $10.2 \%$ & $6.8 \%$ & $12.6 \%$ & $7.7 \%$ & $8.9 \%$ & $2.4 \%$ \\
\hline & Children & $11.5 \%$ & $7.9 \%$ & $17.3 \%$ & $8.3 \%$ & $12.4 \%$ & $3.3 \%$ \\
\hline & Active age & $11.1 \%$ & $7.8 \%$ & $13.3 \%$ & $8.4 \%$ & $8.8 \%$ & $2.7 \%$ \\
\hline & Elderly & $4.9 \%$ & $1.2 \%$ & $3.1 \%$ & $4.6 \%$ & $4.6 \%$ & $0.3 \%$ \\
\hline \multirow{4}{*}{ Germany } & Total & $13.4 \%$ & $10.3 \%$ & $18.2 \%$ & $8.0 \%$ & $14.6 \%$ & $5.4 \%$ \\
\hline & Children & $12.6 \%$ & $11.7 \%$ & $22.9 \%$ & $5.9 \%$ & $21.5 \%$ & $6.7 \%$ \\
\hline & Active age & $11.7 \%$ & $9.6 \%$ & $17.1 \%$ & $7.3 \%$ & $15.4 \%$ & $4.4 \%$ \\
\hline & Elderly & $19.9 \%$ & $11.3 \%$ & $17.9 \%$ & $12.3 \%$ & $5.7 \%$ & $7.6 \%$ \\
\hline \multirow{4}{*}{ Greece } & Total & $16.0 \%$ & $11.1 \%$ & $17.6 \%$ & $11.5 \%$ & $8.7 \%$ & $4.5 \%$ \\
\hline & Children & $19.5 \%$ & $15.0 \%$ & $24.6 \%$ & $12.5 \%$ & $8.9 \%$ & $7.1 \%$ \\
\hline & Active age & $17.3 \%$ & $12.5 \%$ & $19.4 \%$ & $12.4 \%$ & $9.5 \%$ & $4.8 \%$ \\
\hline & Elderly & $8.2 \%$ & $2.2 \%$ & $4.6 \%$ & $7.1 \%$ & $5.4 \%$ & $1.1 \%$ \\
\hline \multirow{4}{*}{ Hungary } & Total & $17.4 \%$ & $10.0 \%$ & $19.4 \%$ & $14.8 \%$ & $4.7 \%$ & $2.6 \%$ \\
\hline & Children & $21.3 \%$ & $14.9 \%$ & $27.7 \%$ & $17.3 \%$ & $6.5 \%$ & $4.0 \%$ \\
\hline & Active age & $18.1 \%$ & $10.6 \%$ & $19.9 \%$ & $15.5 \%$ & $4.3 \%$ & $2.6 \%$ \\
\hline & Elderly & $10.8 \%$ & $2.6 \%$ & $8.8 \%$ & $9.6 \%$ & $4.3 \%$ & $1.1 \%$ \\
\hline \multirow{3}{*}{ Ireland } & Total & $22.6 \%$ & $16.3 \%$ & $24.5 \%$ & $15.1 \%$ & $9.9 \%$ & $7.5 \%$ \\
\hline & Children & $27.7 \%$ & $22.6 \%$ & $35.7 \%$ & $16.3 \%$ & $12.0 \%$ & $11.5 \%$ \\
\hline & Active age & $22.3 \%$ & $17.0 \%$ & $24.6 \%$ & $14.8 \%$ & $10.7 \%$ & $7.5 \%$ \\
\hline
\end{tabular}




\begin{tabular}{|c|c|c|c|c|c|c|c|}
\hline & Elderly & $16.4 \%$ & $3.2 \%$ & $7.1 \%$ & $14.9 \%$ & $2.3 \%$ & $1.5 \%$ \\
\hline \multirow{4}{*}{ Italy } & Total & $19.5 \%$ & $13.1 \%$ & $24.3 \%$ & $12.7 \%$ & $4.6 \%$ & $6.8 \%$ \\
\hline & Children & $24.3 \%$ & $18.0 \%$ & $32.8 \%$ & $14.1 \%$ & $6.4 \%$ & $10.2 \%$ \\
\hline & Active age & $20.5 \%$ & $14.3 \%$ & $26.1 \%$ & $13.5 \%$ & $4.7 \%$ & $7.0 \%$ \\
\hline & Elderly & $12.3 \%$ & $5.0 \%$ & $11.6 \%$ & $9.1 \%$ & $2.9 \%$ & $3.2 \%$ \\
\hline \multirow{4}{*}{ Luxembourg } & Total & $12.7 \%$ & $5.8 \%$ & $23.3 \%$ & $9.6 \%$ & $5.4 \%$ & $3.0 \%$ \\
\hline & Children & $15.0 \%$ & $6.1 \%$ & $33.4 \%$ & $11.2 \%$ & $8.5 \%$ & $3.8 \%$ \\
\hline & Active age & $13.0 \%$ & $6.5 \%$ & $23.6 \%$ & $9.8 \%$ & $5.0 \%$ & $3.3 \%$ \\
\hline & Elderly & $7.2 \%$ & $1.4 \%$ & $5.8 \%$ & $6.6 \%$ & $2.6 \%$ & $0.7 \%$ \\
\hline \multirow{4}{*}{ Poland } & Total & $16.4 \%$ & $7.0 \%$ & $15.5 \%$ & $13.4 \%$ & $7.2 \%$ & $3.1 \%$ \\
\hline & Children & $15.6 \%$ & $6.5 \%$ & $16.7 \%$ & $11.6 \%$ & $9.9 \%$ & $4.0 \%$ \\
\hline & Active age & $17.3 \%$ & $7.5 \%$ & $16.2 \%$ & $14.3 \%$ & $6.6 \%$ & $2.9 \%$ \\
\hline & Elderly & $13.4 \%$ & $4.6 \%$ & $10.6 \%$ & $10.9 \%$ & $6.8 \%$ & $2.5 \%$ \\
\hline \multirow{4}{*}{ Portugal } & Total & $17.9 \%$ & $11.1 \%$ & $19.6 \%$ & $12.4 \%$ & $7.7 \%$ & $5.6 \%$ \\
\hline & Children & $23.7 \%$ & $17.0 \%$ & $28.1 \%$ & $14.7 \%$ & $8.9 \%$ & $9.0 \%$ \\
\hline & Active age & $18.4 \%$ & $11.5 \%$ & $20.2 \%$ & $12.9 \%$ & $7.8 \%$ & $5.5 \%$ \\
\hline & Elderly & $10.6 \%$ & $4.2 \%$ & $9.2 \%$ & $8.0 \%$ & $6.3 \%$ & $2.5 \%$ \\
\hline \multirow{4}{*}{$\begin{array}{l}\text { Slovak } \\
\text { Republic }\end{array}$} & Total & $14.8 \%$ & $10.2 \%$ & $14.5 \%$ & $11.3 \%$ & $4.1 \%$ & $3.5 \%$ \\
\hline & Children & $20.5 \%$ & $16.2 \%$ & $22.2 \%$ & $13.5 \%$ & $6.2 \%$ & $7.0 \%$ \\
\hline & Active age & $13.4 \%$ & $9.7 \%$ & $14.0 \%$ & $10.5 \%$ & $4.0 \%$ & $2.8 \%$ \\
\hline & Elderly & $14.5 \%$ & $4.5 \%$ & $6.6 \%$ & $12.0 \%$ & $2.1 \%$ & $2.5 \%$ \\
\hline \multirow{4}{*}{ Slovenia } & Total & $8.3 \%$ & $2.1 \%$ & $11.6 \%$ & $7.0 \%$ & $7.0 \%$ & $1.3 \%$ \\
\hline & Children & $2.1 \%$ & $0.9 \%$ & $9.8 \%$ & $1.6 \%$ & $9.0 \%$ & $0.5 \%$ \\
\hline & Active age & $8.3 \%$ & $2.7 \%$ & $13.0 \%$ & $6.5 \%$ & $7.0 \%$ & $1.8 \%$ \\
\hline & Elderly & $15.2 \%$ & $1.4 \%$ & $8.5 \%$ & $14.9 \%$ & $4.9 \%$ & $0.4 \%$ \\
\hline \multirow{4}{*}{ Spain } & Total & $21.0 \%$ & $10.5 \%$ & $24.0 \%$ & $17.8 \%$ & $2.4 \%$ & $3.2 \%$ \\
\hline & Children & $30.7 \%$ & $16.7 \%$ & $36.1 \%$ & $25.4 \%$ & $1.9 \%$ & $5.2 \%$ \\
\hline & Active age & $22.0 \%$ & $10.9 \%$ & $24.8 \%$ & $18.7 \%$ & $2.4 \%$ & $3.3 \%$ \\
\hline & Elderly & $5.4 \%$ & $1.2 \%$ & $6.2 \%$ & $4.8 \%$ & $3.0 \%$ & $0.5 \%$ \\
\hline
\end{tabular}

Source: Authors' calculations based on HFCS wave 2 data and EUROMOD simulations. 
Table A.3. Poverty lines applied in the different approaches

\begin{tabular}{|c|c|c|c|c|c|c|c|}
\hline \multirow{2}{*}{ Country } & \multirow{2}{*}{$\begin{array}{l}\text { EUROSTAT } \\
\text { poverty } \\
\text { line }\end{array}$} & \multirow{2}{*}{$\begin{array}{l}\text { Income } \\
\text { poverty } \\
\text { line }\end{array}$} & \multirow{2}{*}{$\begin{array}{l}\text { Wealth } \\
\text { poverty } \\
\text { line }\end{array}$} & \multicolumn{2}{|c|}{$\begin{array}{l}\text { Income-annuitized net } \\
\text { wealth (restricted net } \\
\text { wealth, main text) }\end{array}$} & \multicolumn{2}{|c|}{$\begin{array}{c}\text { Income-annuitized net } \\
\text { wealth (total net } \\
\text { wealth, appendix) }\end{array}$} \\
\hline & & & & $\begin{array}{l}\text { Poverty } \\
\text { line }\end{array}$ & $\begin{array}{c}\text { Difference } \\
\text { with income } \\
\text { poverty line }\end{array}$ & $\begin{array}{l}\text { Poverty } \\
\text { line }\end{array}$ & $\begin{array}{c}\text { Difference } \\
\text { with income } \\
\text { poverty line }\end{array}$ \\
\hline Austria & 14,851 & 13,040 & 3,260 & 14,246 & 1,206 (9.3\%) & 16,334 & 3,295 (25.3\%) \\
\hline Belgium & 13,670 & 12,509 & 3,127 & 13,443 & 934 (7.5\%) & 16,158 & $3,649(29.2 \%)$ \\
\hline Cyprus & 8,698 & 7,465 & 1,866 & 8,818 & 1,353 (18.1\%) & 10,391 & 2,926 (39.2\%) \\
\hline Estonia & 5,631 & 6,001 & 1,500 & 6,502 & 501 (8.3\%) & 7,395 & $1,392(23.2 \%)$ \\
\hline Finland & 14,392 & 14,829 & 3,707 & 15,046 & 216 (1.5\%) & 16,923 & $2,094(14.1 \%)$ \\
\hline France & 13,246 & 10,853 & 2,713 & 11,048 & 195 (1.8\%) & 12,623 & $1,770(16.3 \%)$ \\
\hline Germany & 13,152 & 12,598 & 3,149 & 13,127 & $529(4.2 \%)$ & 14,749 & 2,151 (17.1\%) \\
\hline Greece & 4,560 & 5,617 & 1,404 & 5,890 & 273 (4.9\%) & 6,815 & $1,211(21.6 \%)$ \\
\hline Hungary & 2,993 & 2,626 & 656 & 2,813 & 187 (7.1\%) & 3,477 & 851 (32.4\%) \\
\hline Ireland & 13,727 & 13,416 & 3,354 & 14,585 & $1,168(8.7 \%)$ & 16,340 & $2,924(21.8 \%)$ \\
\hline Italy & 9,925 & 8,286 & 2,071 & 8,668 & 382 (4.6\%) & 10,918 & 2,632 (31.8\%) \\
\hline Luxembourg & 21,645 & 20,758 & 5,189 & 23,010 & $2,252(10.8 \%)$ & 29,476 & $8,718(42.0 \%)$ \\
\hline Poland & 3,567 & 3,946 & 987 & 4,259 & 313 (7.9\%) & 5,185 & $1,239(31.4 \%)$ \\
\hline Portugal & 5,443 & 5,298 & 1,325 & 5,875 & 576 (10.9\%) & 6,724 & $1,426(26.9 \%)$ \\
\hline Slovak Republic & 4,310 & 4,144 & 1,036 & 4,268 & $124(3.0 \%)$ & 5,066 & 921 (22.2\%) \\
\hline Slovenia & 7,628 & 5,293 & 1,323 & 5,732 & 438 (8.3\%) & 6,955 & $1,643(30.9 \%)$ \\
\hline Spain & 8,522 & 8,127 & 2,032 & 9,260 & 1,132 (13.9\%) & 11,863 & 3,735 (46.0\%) \\
\hline
\end{tabular}

Note: The income poverty line refers to conventional poverty line of $60 \%$ of national median equivalised household disposable income calculated based on the EUROMOD simulated disposable incomes for the HFCS gross incomes, this poverty line is also used in the annuitization approach without adapting the poverty line and in the two-dimensional approach. The wealth poverty line is equal to $1 / 4^{\text {th }}$ of the income poverty line. The income-annuitized net wealth poverty line is calculated as $60 \%$ of national median equivalised household disposable income+ annuitized net wealth (net value of owner-occupied housing and private pension savings not included in the restricted wealth concept which is used in the main text, while they are included in the net wealth concept for which poverty rates are shown in the appendix). All poverty lines are in euros.

Source: EUROSTAT and authors' calculations based on HFCS wave 2 data and EUROMOD simulations. 
Table A.4. Socio-demographic profile of joint income-wealth poor by reason for being poor

\begin{tabular}{|c|c|c|c|c|c|c|c|c|c|c|c|c|}
\hline & \multicolumn{6}{|c|}{ Annuitized poor (adjusted poverty line) } & \multicolumn{6}{|c|}{ Twice poor } \\
\hline & \multicolumn{2}{|c|}{$\begin{array}{c}\text { Non-over- } \\
\text { indebted }\end{array}$} & \multicolumn{2}{|c|}{$\begin{array}{c}\text { Over- } \\
\text { indebted } \\
\text { asset poor }\end{array}$} & \multicolumn{2}{|c|}{$\begin{array}{c}\text { Over } \\
\text { indebted } \\
\text { asset non- } \\
\text { poor }\end{array}$} & \multicolumn{2}{|c|}{$\begin{array}{c}\text { Non-over- } \\
\text { indebted }\end{array}$} & \multicolumn{2}{|c|}{$\begin{array}{c}\text { Over- } \\
\text { indebted } \\
\text { asset poor }\end{array}$} & \multicolumn{2}{|c|}{$\begin{array}{c}\text { Over } \\
\text { indebted } \\
\text { asset non- } \\
\text { poor } \\
\end{array}$} \\
\hline $16-34$ years & 1.56 & $* * *$ & 1.73 & $* * *$ & 1.87 & $* * *$ & 1.26 & $* * *$ & 1.25 & $* *$ & 1.49 & $* *$ \\
\hline $35-54$ years & 1.47 & $* * *$ & 1.46 & $* * *$ & 1.41 & $*$ & 1.29 & $* * *$ & 1.25 & $* * *$ & 1.49 & $* * *$ \\
\hline $75+$ years & 0.67 & $* * *$ & 0.65 & $* * *$ & 0.29 & $* * *$ & 0.67 & $* * *$ & 0.65 & $* * *$ & 0.19 & $* * *$ \\
\hline Gender (ref: male) & 1.56 & $* * *$ & 1.54 & $* * *$ & 1.32 & $* *$ & 1.63 & $* * *$ & 1.62 & $* * *$ & 1.17 & \\
\hline \multicolumn{13}{|l|}{ Education (ref: tertiary) } \\
\hline No or primary & 5.05 & $* * *$ & 8.10 & $* * *$ & 3.14 & $* * *$ & 8.06 & $* * *$ & 9.17 & $* * *$ & 2.70 & $* * *$ \\
\hline $\begin{array}{l}\text { Secondary } \\
\text { Labour market status } \\
\text { employee) }\end{array}$ & 3.02 & $* * *$ & 3.97 & $* * *$ & 2.72 & $* * *$ & 3.97 & $* * *$ & 3.82 & $* * *$ & 2.71 & $* * *$ \\
\hline Self-employed & 1.48 & $* * *$ & 0.92 & & 2.90 & $* * *$ & 0.31 & $* * *$ & 0.69 & $* *$ & 2.50 & $* * *$ \\
\hline Unemployed & 7.74 & $* * *$ & 15.54 & $* * *$ & 4.40 & $* * *$ & 6.89 & $* * *$ & 14.30 & $* * *$ & 5.32 & $* * *$ \\
\hline Retired & 2.02 & $* * *$ & 3.26 & $* * *$ & 1.44 & & 2.06 & $* * *$ & 3.11 & $* * *$ & 1.95 & $* * *$ \\
\hline Inactive & 5.81 & $* * *$ & 9.48 & $* * *$ & 1.50 & & 5.71 & $* * *$ & 9.23 & $* * *$ & 4.41 & $* * *$ \\
\hline \multicolumn{13}{|c|}{ Household type (ref: couple) } \\
\hline Single & 1.94 & $* * *$ & 3.27 & $* * *$ & 1.67 & $* *$ & 2.16 & $* * *$ & 3.41 & $* * *$ & 1.39 & \\
\hline Single parent & 1.43 & $* * *$ & 2.04 & $* * *$ & 5.23 & $* * *$ & 1.93 & $* * *$ & 1.24 & & 6.11 & $* * *$ \\
\hline Couple with children & 1.51 & $* * *$ & 1.94 & $* * *$ & 0.96 & & 1.90 & $* * *$ & 1.81 & $* * *$ & 1.56 & $* *$ \\
\hline Other & 1.82 & $* * *$ & 2.90 & $* * *$ & 1.78 & $* * *$ & 2.22 & $* * *$ & 2.94 & $* * *$ & 1.75 & $* * *$ \\
\hline \multicolumn{13}{|c|}{ Tenure status (ref: owner) } \\
\hline Owner with mortgage & 0.92 & $* *$ & 1.33 & $* * *$ & 1.09 & & 0.99 & & 1.27 & $* * *$ & 0.94 & \\
\hline Tennant/free user & 1.94 & $* * *$ & 3.56 & $* * *$ & 1.85 & $* * *$ & 3.50 & $* * *$ & 4.50 & $* * *$ & 1.80 & $* * *$ \\
\hline \multicolumn{13}{|l|}{ Country (ref: Austria) } \\
\hline Belgium & 2.66 & $* * *$ & 1.23 & & 0.58 & & 4.70 & $* * *$ & 1.47 & & 2.15 & $* *$ \\
\hline Cyprus & 2.53 & $* * *$ & 3.18 & $* * *$ & 8.18 & $* * *$ & 2.30 & $* * *$ & 1.25 & & 11.52 & $* * *$ \\
\hline Estonia & 5.05 & $* * *$ & 3.04 & $* * *$ & 0.46 & & 9.01 & $* * *$ & 5.83 & $* * *$ & 1.56 & \\
\hline Finland & 0.66 & $* * *$ & 1.01 & & 3.40 & $* * *$ & 1.53 & $* * *$ & 1.46 & $* *$ & 4.21 & $* * *$ \\
\hline France & 1.00 & & 0.24 & $* * *$ & 1.77 & $* *$ & 1.00 & & 0.24 & $* * *$ & 2.12 & $* *$ \\
\hline Germany & 1.64 & $* * *$ & 1.50 & $* * *$ & 2.58 & $* * *$ & 2.47 & $* * *$ & 2.66 & $* * *$ & 1.89 & $*$ \\
\hline Greece & 1.68 & $* * *$ & 2.27 & $* * *$ & 0.38 & $* *$ & 3.22 & $* * *$ & 4.07 & $* * *$ & 2.00 & $* *$ \\
\hline Hungary & 2.63 & $* * *$ & 5.02 & $* * *$ & 2.65 & $* * *$ & 3.72 & $* * *$ & 8.42 & $* * *$ & 3.86 & $* * *$ \\
\hline Ireland & 3.44 & $* * *$ & 2.86 & $* * *$ & 1.95 & $* *$ & 4.26 & $* * *$ & 4.15 & $* * *$ & 4.50 & $* * *$ \\
\hline Italy & 2.49 & $* * *$ & 1.89 & $* * *$ & 0.26 & $* * *$ & 4.56 & $* * *$ & 3.32 & $* * *$ & 2.34 & $* * *$ \\
\hline Luxembourg & 2.37 & $* * *$ & 1.89 & $* * *$ & 3.04 & $* * *$ & 1.82 & $* * *$ & 0.85 & & 3.43 & $* * *$ \\
\hline Poland & 2.09 & $* * *$ & 3.05 & $* * *$ & 0.20 & $* * *$ & 2.51 & $* * *$ & 5.42 & $* * *$ & 1.14 & \\
\hline Portugal & 1.89 & $* * *$ & 1.35 & $* *$ & 0.82 & & 3.27 & $* * *$ & 2.00 & $* * *$ & 1.76 & \\
\hline Slovak Republic & 1.62 & $* * *$ & 6.43 & $* * *$ & 0.23 & $* * *$ & 3.45 & $* * *$ & 15.65 & $* * *$ & 1.91 & \\
\hline Slovenia & 1.05 & & 1.09 & & 0.95 & & 1.73 & $* * *$ & 1.75 & $* * *$ & 0.99 & \\
\hline Spain & 2.93 & $* * *$ & 1.27 & & 3.33 & $* * *$ & 1.64 & $* * *$ & 0.75 & & 3.23 & $* * *$ \\
\hline Constant & 0.01 & $* * *$ & 0.00 & $* * *$ & 0.00 & $* * *$ & 0.00 & $* * *$ & 0.00 & $* * *$ & 0.00 & $* * *$ \\
\hline$R^{2}$ & \multicolumn{6}{|c|}{0.1711} & \multicolumn{6}{|c|}{0.2182} \\
\hline
\end{tabular}

Source: Authors' calculations based on HFCS wave 2 data and EUROMOD simulations. 


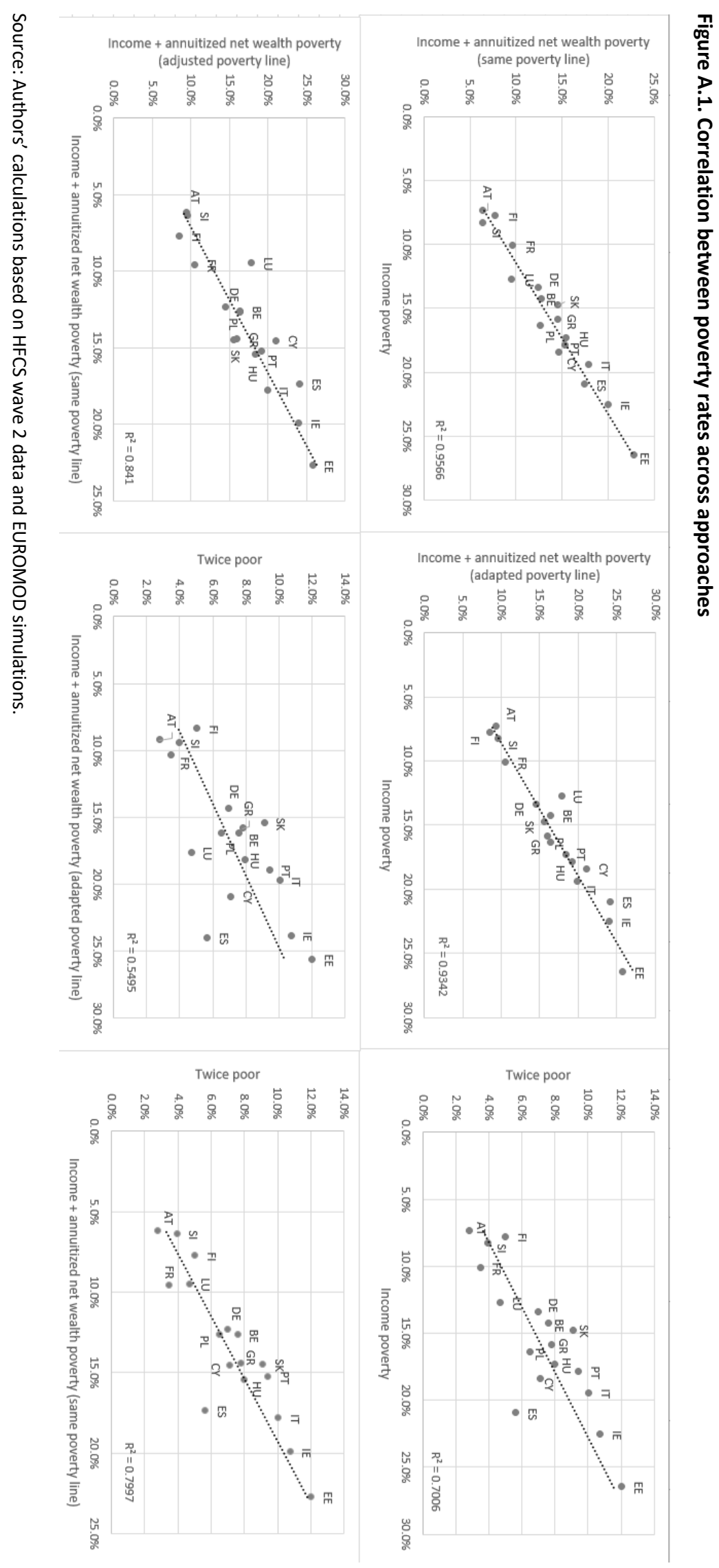




\section{Appendix 2: Summary of HFCS-EUROMOD simulations}

An important shortcoming of the HFCS data as they are supplied by the European Central Bank is that they cover income components gross of taxes and social insurance contributions ${ }^{12}$. Therefore, we have included the HFCS as input data for the EU-wide tax-benefit microsimulation model EUROMOD. In this appendix we provide a brief overview of how the HFCS data and the model have been combined and how the results compare to those of the EU-SILC dataset, which is standardly used in the EU to calculate poverty rates and is also the standard input dataset for EUROMOD. For more details we refer to Boone et al. (2019).

EUROMOD is a tax-benefit microsimulation model covering all $27 \mathrm{EU}$ countries and the UK within a harmonised framework. It takes information on market incomes and other relevant information from an underlying database in order to simulate non-contributory cash benefit entitlements and liabilities for direct taxes and socialinsurance contributions based on the tax-benefit rules in place (Sutherland and Figari, 2013). In order to construct the HFCS input dataset for EUROMOD we largely followed the same procedures as those that are used for the EU-SILC input dataset. The majority of the variables needed for the simulations of taxes and benefits are available in the HFCS. Although social benefits are already included in the original HFCS dataset, we decided to use the amounts simulated by EUROMOD if these turned out to be larger than the ones observed in the original data.

The reason for this is that social benefits appear to be underestimated in the original data as they are surveyed only with a limited set of questions (with the exception of pensions and unemployment benefits all benefits are taken together in a single variable). In EUROMOD we can simulate several important social benefits based on other observed information, i.e. mainly child benefits and social assistance. Of course there are some benefits which are not observed in HFCS and can also not be simulated in EUROMOD, but these often entail small benefits received by a limited number of people, so that the effects on the simulation results are likely to be small. The simulations of liabilities for personal income taxes and social insurance contributions can be carried out relatively straightforward, with the exception of a few very specific tax deductions or credits in some countries.

A comparison of some summary statistics of market and disposable incomes between the HFCS-based EUROMOD simulations and the EU-SILC based simulations is presented in Table A.5 (for the income reference year). It is

\footnotetext{
12 For Italy and Poland the non-core variable list of the HFCS provides information on disposable incomes and for Finland on taxes and social contributions paid, but the definition of disposable incomes "varies country by country, and has not been harmonised" (HFCN, 2016a, p.73 footnote 38).
} 
clear that comparability between the results of EM-HFCS and EM-SILC varies widely across countries. Results are close to each other for Finland, Portugal and Slovakia, while they diverge rather strongly for Austria, Estonia, France and Slovenia. Differences are usually larger for market income than for disposable income and larger for the mean than for the median. The differences mostly reflect higher amounts in EM-HFCS than in EM-SILC, which might be related to the oversampling that is applied in the HFCS (see HFCN, 2016a). Gini coefficients are often also higher in EM-HFCS than in EM-SILC.

As mentioned in the data and methods section of the paper, we have used the 2017 tax and benefit rules to simulate disposable incomes. To this end monetary variables related to income, but also assets and debts, have been uprated from their HFCS income reference period to 2017 price levels. The HFCS income reference period is mostly 2013, it is 2010 for Spain, 2012 for Estonia, Portugal and Ireland and 2014 for France, Italy and Hungary

(HFCN, 2016a). For income related variables the uprating is as for EU-SILC mostly done using the Consumer Price Index (CPI), while assets and debt are uprated based on their corresponding aggregates in the national accounts.

\section{References}

Boone, J. et al., 2019. EWIGE 2 - Update and extension of the EUROMOD wealth taxation project, sl: JRC

Working papers on Taxation and Structural Reforms No. 2019/07.

Eurosystem Household Finance and Consumption Network (HFCN), 2016a. The Household Finance and Consumption Survey: methodological report for the second wave, sl: ECB Statistics Paper No.17.

Sutherland, H. \& Figari, F., 2013. EUROMOD: the European Union tax-benefit microsimulation model. International Journal of Microsimulation, 6(1), pp. 4-26. 


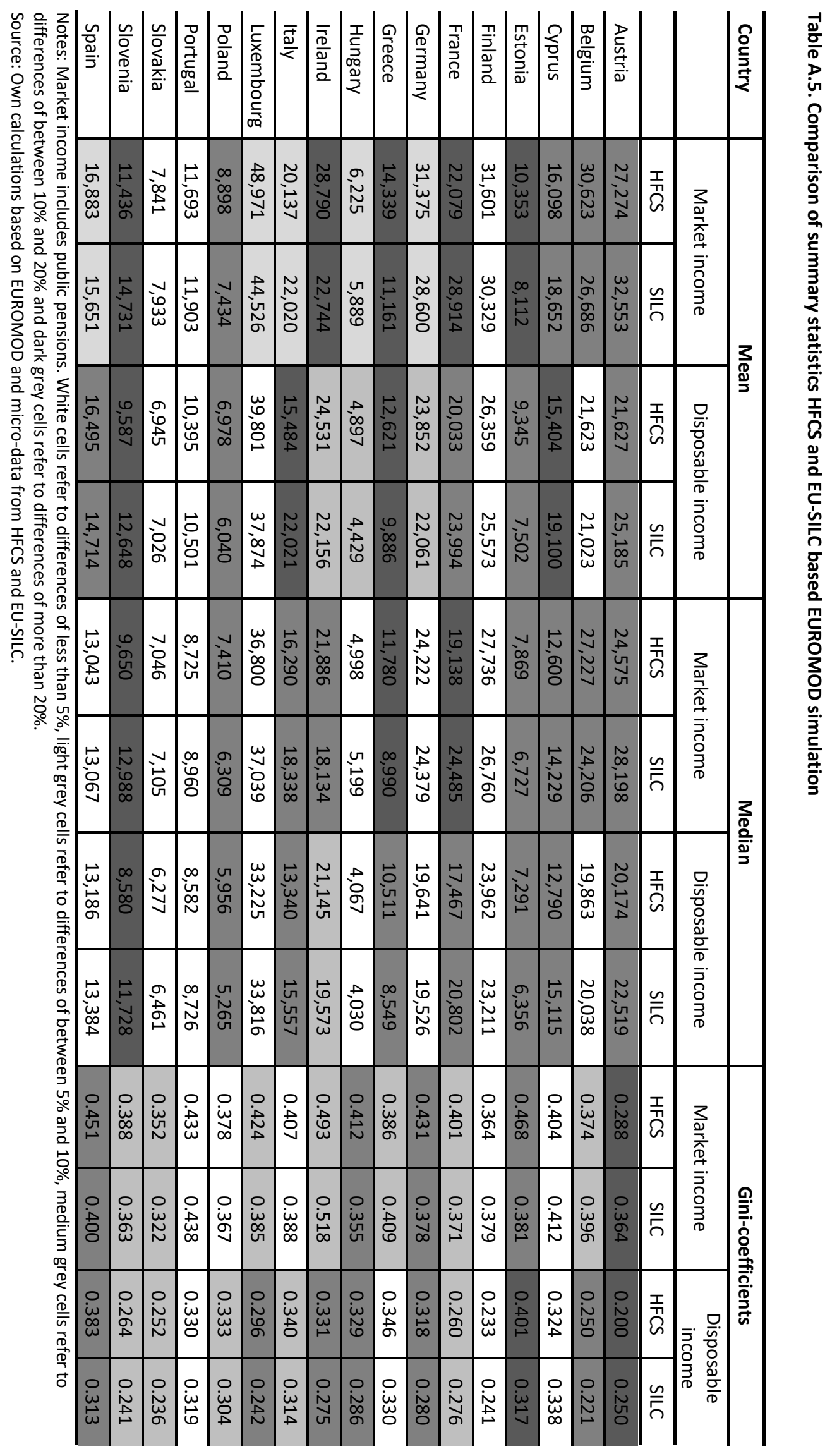

